\title{
Springtime warming and reduced snow cover from carbonaceous particles
}

\author{
M. G. Flanner ${ }^{1}$, C. S. Zender ${ }^{2}$, P. G. Hess ${ }^{1,3}$, N. M. Mahowald ${ }^{1,3}$, T. H. Painter ${ }^{4}$, V. Ramanathan ${ }^{5}$, and P. J. Rasch ${ }^{1}$ \\ ${ }^{1}$ National Center for Atmospheric Research, Boulder CO, USA \\ ${ }^{2}$ University of California, Irvine CA, USA \\ ${ }^{3}$ Cornell University, Ithaca NY, USA \\ ${ }^{4}$ University of Utah, Salt Lake City UT, USA \\ ${ }^{5}$ Scripps Institute of Oceanography, University of California-San Diego, La Jolla CA, USA
}

Received: 24 September 2008 - Published in Atmos. Chem. Phys. Discuss.: 26 November 2008

Revised: 31 March 2009 - Accepted: 31 March 2009 - Published: 7 April 2009

\begin{abstract}
Boreal spring climate is uniquely susceptible to solar warming mechanisms because it has expansive snow cover and receives relatively strong insolation. Carbonaceous particles can influence snow coverage by warming the atmosphere, reducing surface-incident solar energy (dimming), and reducing snow reflectance after deposition (darkening). We apply a range of models and observations to explore impacts of these processes on springtime climate, drawing several conclusions: 1) Nearly all atmospheric particles (those with visible-band single-scatter albedo less than 0.999), including all mixtures of black carbon (BC) and organic matter $(\mathrm{OM})$, increase net solar heating of the atmosphere-snow column. 2) Darkening caused by small concentrations of particles within snow exceeds the loss of absorbed energy from concurrent dimming, thus increasing solar heating of snowpack as well (positive net surface forcing). Over global snow, we estimate 6-fold greater surface forcing from darkening than dimming, caused by BC+OM. 3) Equilibrium climate experiments suggest that fossil fuel and biofuel emissions of $\mathrm{BC}+\mathrm{OM}$ induce 95\% as much springtime snow cover loss over Eurasia as anthropogenic carbon dioxide, a consequence of strong snowalbedo feedback and large $\mathrm{BC}+\mathrm{OM}$ emissions from Asia. 4) Of 22 climate models contributing to the IPCC Fourth Assessment Report, 21 underpredict the rapid warming $\left(0.64^{\circ} \mathrm{C}\right.$ decade $\left.^{-1}\right)$ observed over springtime Eurasia since 1979. Darkening from natural and anthropogenic sources of $\mathrm{BC}$ and mineral dust exerts 3-fold greater forcing on spring-
\end{abstract}

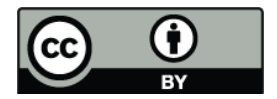

Correspondence to: M. G. Flanner (mflanner@ucar.edu) time snow over Eurasia $\left(3.9 \mathrm{~W} \mathrm{~m}^{-2}\right)$ than North America $\left(1.2 \mathrm{~W} \mathrm{~m}^{-2}\right)$. Inclusion of this forcing significantly improves simulated continental warming trends, but does not reconcile the low bias in rate of Eurasian spring snow cover decline exhibited by all models, likely because $\mathrm{BC}$ deposition trends are negative or near-neutral over much of Eurasia. Improved Eurasian warming may therefore relate more to darkeninginduced reduction in mean snow cover.

\section{Introduction}

Understanding controls of snow cover evolution is important because 1) cryospheric response to climate forcing largely determines climate sensitivity (e.g., Lemke et al., 2007; Levis et al., 2007), and 2) most of the interannual variability in mid- and high-latitude planetary albedo is caused by changes in snow and sea-ice cover (Qu and Hall, 2005). Atmospheric particles have short lifetimes, but influence the snowpack energy budget via several mechanisms. First, they reduce downwelling surface insolation (dimming) (e.g., Ogren and Charlson, 1983), thus decreasing absorbed solar energy by snowpack. Second, deposited particles reduce snow reflectance (surface darkening) (e.g., Warren and Wiscombe, 1980), counteracting the dimming effect. Finally, absorbing particles warm the troposphere via solar heating. This warming may transfer thermal energy into snow and drive earlier melt, but may also stabilize the atmosphere and reduce surface-air energy exchange. Here, we strive to understand the relative and combined effects of these processes on continental snow cover.

Published by Copernicus Publications on behalf of the European Geosciences Union. 
Several recent studies highlight the role of black carbon (BC) in cryosphere perturbation. BC measurements in Mt. Everest ice (Ming et al., 2008) show mixing ratios that produced a summer darkening effect of $4.5 \mathrm{~W} \mathrm{~m}^{-2}$ in 2001 . Ramanathan et al. (2007) suggest that brown clouds contribute as much surface air warming over the Himalaya as anthropogenic greenhouse gases. Early 20th century BC concentrations in Greenland ice were sufficient to perturb the summertime surface energy budget by $\sim 3 \mathrm{~W} \mathrm{~m}^{-2}$ over the Arctic (McConnell et al., 2007), where BC is transported from distant regions (Koch and Hansen, 2005; Stohl, 2006). Estimates of present-day global-mean radiative forcing from $\mathrm{BC}$ in snow are only $\sim 0.04-0.20 \mathrm{~W} \mathrm{~m}^{-2}$ (Hansen and Nazarenko, 2004; Jacobson, 2004; Flanner et al., 2007), but climate models suggest this mechanism has greater efficacy than any other anthropogenic agent (Hansen et al., 2005; Flanner et al., 2007), owing largely to its effectiveness in removing snow cover. Snow-albedo feedback is strongest during boreal spring (Hall and Qu, 2006), when a large portion of the Northern Hemisphere is snow-covered and exposed to intense insolation (see Fig. 2). Finally, research showing that desert dust causes snow to ablate one month early in the San Juan Mountains (Painter et al., 2007) further highlights the strong sensitivity of springtime snowpack evolution to albedo change.

Recognizing the unique susceptibility of springtime climate to light-absorbing matter, we examine the influence of carbonaceous particles during March-May. Over the last 30 years, this season has experienced a significant decline in continental snow cover (e.g., Déry and Brown, 2007) and rapid warming over mid- to high-latitude land surface (e.g., Trenberth et al., 2007). We begin with studies of solar radiative terms in an atmosphere-snow column, and continue with global climate simulations. On both scales we find that surface darkening caused by realistic amounts of particles mixed with snow outweighs the dimming influence of particles in the atmosphere. On the global scale, positive surface and atmosphere forcings from carbonaceous particles drive significant reductions in springtime snow cover. In this context, we examine the recent, rapid springtime warming observed over Asia, where $\mathrm{BC}$ emissions rose by roughly $50 \%$ during 1980-2000 (Bond et al., 2007).

\section{Methods}

\subsection{Column radiation model}

To examine surface and top-of-atmosphere (TOA) radiative forcing caused by particles over and within snowpack, we applied the Shortwave Narrowband (SWNB) model (Zender et al., 1997). SWNB utilizes the Discrete Ordinates Radiative Transfer (DISORT) model (Stamnes et al., 1988) and solves for fluxes in 1690 spectral bands from $0.17-5.0 \mu \mathrm{m}$. We modify this model to include a single, semi-infinite layer of snow (i.e., thicker than $\sim 20 \mathrm{~cm}$ ) at the bottom of the atmosphere, thus simulating radiation throughout the atmospheresnow column. This approach has been adopted in previous studies (Nolin and Dozier, 1993; Aoki et al., 1999; Munneke et al., 2008), and is preferable, in the current context, to methods which prescribe downwelling flux on snowpack as a boundary condition (e.g., Flanner and Zender, 2006). We report spectrally-integrated daily-mean forcings for a range of aerosol single-scatter albedo (SSA) and particle mixing ratio within snow. We prescribe SSA and extinction optical depth at $500 \mathrm{~nm}$, and scale the spectral distributions of these properties according to Mie properties of sulfate (for SSA $\geq 0.9999$ ), water-soluble organic matter (Hess et al., 1998) (for SSA $\geq 0.7$ ), and black carbon (Chang and Charalampopoulos, 1990; Bond and Bergstrom, 2006) (for SSA <0.7). We estimate fluxes at half-hour resolution for an atmosphere-snow column at $45^{\circ} \mathrm{N}$ on 1 April, assuming a snowpack effective grain size of $200 \mu \mathrm{m}$ (representative of fresh or slightly-aged snow). The importance of effective grain size in determining albedo perturbation is discussed in previous studies (Warren and Wiscombe, 1980; Flanner and Zender, 2006; Flanner et al., 2007).

\subsection{Global Climate Model}

Global Climate Model (GCM) experiments were conducted with the National Center for Atmospheric Research (NCAR) Community Atmosphere Model 3.1 (CAM) (e.g., Collins et al., 2006) with resolution $\sim 2.8^{\circ} \times 2.8^{\circ}$ near the equator. Equilibrium climate simulations applied a slab ocean model to allow for fast equilibration, and were forced with constant greenhouse gas levels and monthly-varying, annuallyrepeating concentrations of mineral dust, sulfate, and seasalt from an assimilation (Collins et al., 2001). BC and organic matter $(\mathrm{OM})$ were treated prognostically (Rasch et al., 2000, 2001), with annually-repeating emissions from a global $1^{\circ} \times 1^{\circ}$ inventory (Bond et al., 2004) representing 1996. Emissions of organic carbon from this inventory were multiplied by 1.4 to represent organic matter (Russell, 2003). Hydrophobic species transformed to hydrophilic with an efolding time of 1.2 days. BC optical properties were modified to conform with recent studies (Bond and Bergstrom, 2006; Bond et al., 2006), including an absorption enhancement factor of 1.5 for coated hydrophilic particles, as described by Flanner et al. (2007). Optical properties for OM were from Hess et al. (1998), including relative humidity dependence.

Transient climate simulations were also conducted with CAM 3.1, span 1977-2000, and were forced with timeevolving sea surface temperatures (SSTs) and sea-ice distributions from the Hadley Centre (Rayner et al., 2003). Other time-varying forcing agents applied include greenhouse gases $\left(\mathrm{CO}_{2}, \mathrm{CH}_{4}, \mathrm{~N}_{2} \mathrm{O}\right.$, and CFCs), ozone (Lamarque et al., 2005), volcanic aerosols (Ammann et al., 2003), $\mathrm{SO}_{\mathrm{x}}$ emissions (Smith et al., 2001), BC, and OM. Fossil fuel (FF) 
Table 1. Model experiments.

\begin{tabular}{|c|c|c|c|c|c|c|}
\hline $\begin{array}{l}\text { Experiment } \\
\text { Case }\end{array}$ & $\begin{array}{c}\mathrm{CO}_{2} \\
(\mathrm{ppm})\end{array}$ & $\begin{array}{l}\mathrm{FF}+\mathrm{BF} \mathrm{BC}+\mathrm{OM}^{\mathrm{a}} \\
\text { active in atmos.? }\end{array}$ & $\begin{array}{c}\mathrm{FF}+\mathrm{BF} \mathrm{BC} \\
\text { active in snow? }\end{array}$ & $\begin{array}{c}\mathrm{BB} \mathrm{BC}+\mathrm{OM} \text { and dust } \\
\text { active in atmos.? }\end{array}$ & $\begin{array}{l}\mathrm{BB} B C \text { and dust } \\
\text { active in snow? }\end{array}$ & $\begin{array}{l}\text { Ocean / sea-ice } \\
\text { Configuration }\end{array}$ \\
\hline $\mathrm{PI} 1^{\mathrm{c}}$ & 289 & no & no & no & no & slab \\
\hline PI2 & 380 & no & no & no & no & slab \\
\hline PI3 & 289 & yes & no & no & no & slab \\
\hline PI4 & 289 & no & yes & no & no & slab \\
\hline PI5 & 289 & yes & yes & no & no & slab \\
\hline PI6 & 380 & yes & yes & no & no & slab \\
\hline $\mathrm{PD}^{d}$ & 380 & yes & yes & yes & yes & slab \\
\hline PD2 & 380 & no & no & yes & yes & slab \\
\hline $\mathrm{T} 1^{\mathrm{e}}$ & transient & yes & no & yes & no & prescribed \\
\hline $\mathrm{T} 2$ & transient & yes & yes & yes & yes & prescribed \\
\hline
\end{tabular}

${ }^{a}$ Fossil fuel and biofuel black carbon and organic matter.

$\mathrm{b}$ Biomass burning black carbon and mineral dust.

c "PI" experiments have pre-industrial initial conditions.

d "PD" experiments have present-day initial conditions.

e "T" experiments driven with time-evolving (1977-2000) greenhouse gases, aerosols, sea-ice, and SSTs.

and biofuel (BF) emissions of BC and organic carbon were linearly interpolated from a 5-year resolution historical inventory (Bond et al., 2007). Biomass burning emissions of $\mathrm{BC}$ and $\mathrm{OM}$ were prescribed from the Global Fire Emissions Database (Van der Werf et al., 2006), version 2 (GFEDv2), which spans 1997-2006. Pre-1997 emissions follow Lamarque et al. (2005), and are close to mean 1997-2006 emissions during 1979-2005. Mineral dust aerosols, including emissions, were also treated prognostically (Zender et al., 2003; Mahowald et al., 2006), including four size bins. Dust optical properties were tuned to match global observations (Zender et al., 2009), with $550 \mathrm{~nm} \mathrm{SSA} \mathrm{ranging} \mathrm{from} 0.88$ to 0.99 with decreasing particle size. These simulations were initialized with a mean present-day climatology and were analyzed for trends over 1979-2000, to compare with simulation from other modeling communities (described below). Thus, these experiments have 2 years of spin-up, more than most of the prescribed-SST simulations we will compare with.

Black carbon and mineral dust in snow were treated with the Snow, Ice, and Aerosol Radiative (SNICAR) component of CAM (Flanner et al., 2007), which applies Mie scattering to air/ice/particle mixtures (Wiscombe and Warren, 1980; Warren and Wiscombe, 1980), and a multi-layer radiative transfer approximation (Toon et al., 1989) to represent vertical inhomogeneity in the snow. Organic matter was excluded from snow, as a short sensitivity study indicated negligible global forcing. However, future work will be needed on this, as knowledge of absorption partitioning amongst carbon species improves. After aerosol deposition to the surface, fresh snow and flushing with melt water control the vertical particle profile, influencing radiative transfer through the snow. Snow aging also controls radiative properties via the effective grain size, and is based on a microphysical model (Flanner and Zender, 2006). Model adaptation for use in CAM is described extensively by Flanner et al. (2007). That study showed reasonable agreement between model predictions of BC in surface snow and observations made throughout the world.

In these studies we assumed a new representation of snow cover fraction (Niu and Yang, 2007) that depends on snow depth and density to account for seasonal hysteresis, and which will likely be included in future generations of CAM. We quantified snow covered area (SCA) as the following summation over gridcells within a desired region: $\sum f_{\text {snow }} f_{\text {land }} a$, where $f_{\text {snow }}, f_{\text {land }}$, and $a$ are, respectively, monthly-mean snow cover fraction of the land-covered gridcell portion, land cover fraction of the gridcell, and gridcell area.

Radiative forcings were computed interactively in the atmosphere and snow components of the model, each timestep, as the difference in fluxes with all species present and all species except those whose forcing was being quantified. Thus, they are "instantaneous" forcings, calculated at the top-of-atmosphere and surface for atmospheric aerosols, and at the surface for particles in snow. Instantaneous forcings of aerosols closely approximate their adjusted radiative forcings (Hansen et al., 2005).

\subsection{Global climate experiments}

Configurations of our equilibrium climate experiments are described in Table 1. Experiments tagged "PI" were initialized with pre-industrial climate and form idealized sensitivity studies to assess the relative impacts of anthropogenic $\mathrm{CO}_{2}$ and carbonaceous particles in the atmosphere and snow. 
The two experiments tagged "PD" apply present-day conditions and are more complete representations of current climate, including radiative influence of dust particles and biomass burning smoke in the atmosphere and snow. They were designed to assess impacts of removing all $\mathrm{FF}+\mathrm{BF}$ $\mathrm{BC}+\mathrm{OM}$ from current climate (Jacobson, 2004). In all equilibrium experiments, results were averaged over the final 15 years of 50 year simulations, during which the TOA net energy flux showed no significant trend. Statistical difference between the simulations was determined with two-sided pooled $t$-tests, using realizations from each of the 15 analysis years.

Transient simulations were designed to explore the influence of snow darkening on climate trends from 19792000. Experiments "T1" and "T2" (Table 1) include all timeevolving forcing agents and are identical, except that $\mathrm{T} 2$ includes the influence of snow darkening from black carbon and mineral dust. These experiments each comprise fivemember ensembles, with each member subject to slight perturbations of the initial temperature field. Least-squares linear regression was applied to determine trends and ensemble members used as realizations to determine significance.

\subsection{Observations}

Observed monthly surface air temperature data were obtained from the Climate Research Unit (Brohan et al., 2006) (CRUTEM3 dataset from http://www.cru.uea.ac.uk/cru/data/ temperature/) and NASA Goddard Institute for Space Studies (Hansen et al., 2001) (http://data.giss.nasa.gov/gistemp/). We averaged these data, weighted by area and land cover fraction, from March-May over Eurasia $\left(30-90^{\circ} \mathrm{N}, 348-\right.$ $\left.188^{\circ} \mathrm{E}\right)$ and North America $\left(30-90^{\circ} \mathrm{N}, 188-300^{\circ} \mathrm{E}\right)$. We apply continent-averaged snow cover extent (SCE) data from the National Oceanic and Atmospheric Administration (NOAA), maintained by Rutgers University (Robinson and Frei, 2000) (available at http://climate.rutgers.edu/ snowcover). These observations are based on visible-band satellite imagery from AVHRR, beginning in 1979. Gridded snow cover and sea-ice data from the National Snow and Ice Data Center (Armstrong and Brodzik, 2005) were combined with an assimilation of global surface insolation (Qian et al., 2006), adjusted for cloud cover anomalies, to generate Fig. 2. Statistical trends and confidence intervals for observations were derived using the Mann-Kendall and Theil-Sen techniques. We also apply the "trend-free pre-whitening" technique discussed by Yue et al. (2002) to account for autocorrelation, following a similar approach of Déry and Brown (2007).

\subsection{Climate model data}

We assessed model hindcasts of surface air temperature and snow cover trends using the World Climate Research Programme's (WCRP's) Coupled Model Intercomparison
Project phase 3 (CMIP3) multi-model dataset. We analyzed monthly-resolved output from all simulations classified as either "AMIP" (atmosphere-land models with prescribed SSTs and sea-ice) or "20CM3" (20th century simulations with coupled atmosphere-ocean models). We refer to these two categories of experiments, respectively, as "SST-forced" and "AOGCM." These data contributed to the Intergovernmental Panel on Climate Change (IPCC) Fourth Assessment Report (AR4) and were obtained from: https://esg.llnl.gov: 8443. Most SST-forced simulations begin in 1979, whereas AOGCM experiments begin around 1860. Appendix A lists models examined, number of ensembles analyzed, variables used to derive snow cover extent, and years of analysis. Model numbers in this table correspond with abscissa labels in Figs. 5 and 6.

For models reporting snow cover fraction (SCF), we used this variable to compute large-scale snow cover extent. For models not reporting SCF, we derived it from either snow depth or snow mass, depending on which variables were reported (Appendix A), using the SCF representation from Niu and Yang (2007), and assuming a snow density of $250 \mathrm{~kg} \mathrm{~m}^{-3}$ (Frei et al., 2003). Sensitivity studies varying snow density from $150-350 \mathrm{~kg} \mathrm{~m}^{-3}$ generally altered snow cover trends by less than $15 \%$. The NOAA/Rutgers SCE product does not define fractional snow coverage within gridcells. Therefore, for consistent comparison with this product, we define area-averaged SCE of CMIP3 models as: $\sum f_{\text {land }} a$ for gridcells with $f_{\text {snow }}>0.5$. We found, however, that SCE and SCA trends were similar in most models.

\section{Results and discussion}

\subsection{Column radiative forcing}

We begin by examining the influence of different aerosol mixtures on the energy budget of an atmosphere-snowpack column. Figure 1 shows clear-sky top-of-atmosphere (TOA) and surface solar radiative forcings as a function of particle single-scatter albedo (SSA) at $500 \mathrm{~nm}$, with identical optical properties applied to particles in the atmosphere and snow. Atmospheric extinction optical depth is fixed at 0.2, but the forcing behavior discussed below remains robust under a doubling or halving of this term. Curves are shown for different values of $\alpha$, which describes the ratio of particle mixing ratio in snow $\left(\mathrm{kg} \mathrm{kg}^{-1}\right)$ to atmospheric column bur$\operatorname{den}\left(\mathrm{kg} \mathrm{m}^{-2}\right)$. Surface forcing, in this discussion, represents the combined effect of reduced absorption from atmospheric aerosols and increased absorption from snow darkening.

Several features of Fig. 1 are worth noting. First, aerosol mixtures with SSA $<0.999\left(\right.$ co-SSA $\left.>10^{-3}\right)$ exert a positive TOA forcing over (thick) snow, even with no particles in the underlying snow $(\alpha=0)$. The range of positive forcing includes organic matter (Hess et al., 1998), often considered the "scattering" component of carbonaceous aerosol 
mixtures, as well as weakly absorbing clay minerals like montmorillonite. We note that the range of aerosol SSA producing positive TOA forcing will be reduced over snowpacks thinner than $\sim 20 \mathrm{~cm}$ (Wiscombe and Warren, 1980), as exposure of the underlying surface reduces albedo. The interval between vertical bars "black carbon" and "organic matter" can be considered a reasonable range of effect for carbonaceous aerosol mixtures over snow, where fossil fuel sources are skewed towards BC and biomass burning sources towards OM (e.g., Andreae and Merlet, 2001). Second, the influence of particles in snow increases TOA forcing for mixtures with co-SSA $>10^{-4}$ (and slightly decreases forcing for highly scattering mixtures, like pure sulfate with co$\mathrm{SSA} \sim 10^{-8}$ ). Third, absorbing aerosols in the atmosphere strongly reduce downwelling surface insolation (curve labeled "dimming"), but the resulting surface forcing $(\alpha=0)$ is only weakly negative because most of the reduced downwelling radiation would have been reflected by the bright snowpack (e.g, Cess, 1983). Fourth, and perhaps most important, the darkening effect caused by small mixing ratios of particles in snow $(\alpha>0.01)$ exceeds the reduced absorption from dimming, producing net positive surface forcing. Snow reflectance is easily perturbed because multiple scattering of visible-band photons produces highly actinic flux near the snow surface, enabling very small quantities of particles to absorb a disproportionate amount of radiation (e.g., Warren and Wiscombe, 1980). Later, we report global-mean estimates of dimming and darkening energy components.

The slight non-linearity in Fig. 1 at $\mathrm{co-SSA}=0.3$ occurs where the spectral distributions of extinction cross-section and SSA transition from OM to $\mathrm{BC}$. Because $\mathrm{BC}$ is proportionately more extinctive and darker in the near-infrared spectrum, where snow strongly absorbs, the dimming influence drives a more negative surface forcing. Exacerbating this is the fact that near-infrared snow albedo (beyond $1.1 \mu \mathrm{m})$ is only negligibly perturbed by absorbing particles (e.g., Warren, 1982; Flanner et al., 2007). The near-zero surface forcing depicted for $\alpha=0.01$ becomes slightly more positive with presence of clouds, which absorb some of the nearinfrared radiation contributing to dimming.

The value of $\alpha$ exhibits large variability and depends on processes including deposition efficiency and meltwater scavenging within snowpack. For example, an aerosol plume experiencing little deposition might produce very low $\alpha$, whereas a melting snowpack underlying a pristine atmosphere may exhibit very large $\alpha$. Analysis of 10 years of global climate simulations from Flanner et al. (2007) shows a wide, lognormal distribution of $\alpha$, with area-weighted mean of 0.07. However, during spring (March-May), when hydrophobic particles are retained near the snowpack top, mean Northern Hemisphere $\alpha$ jumps to 0.15 .

Sensitivity of TOA aerosol forcing to underlying surface albedo and cloud cover has long been recognized (e.g., Coakley et al., 1983; Cess, 1983). Recently, positive TOA shortwave forcings have been cited for biomass burning smoke
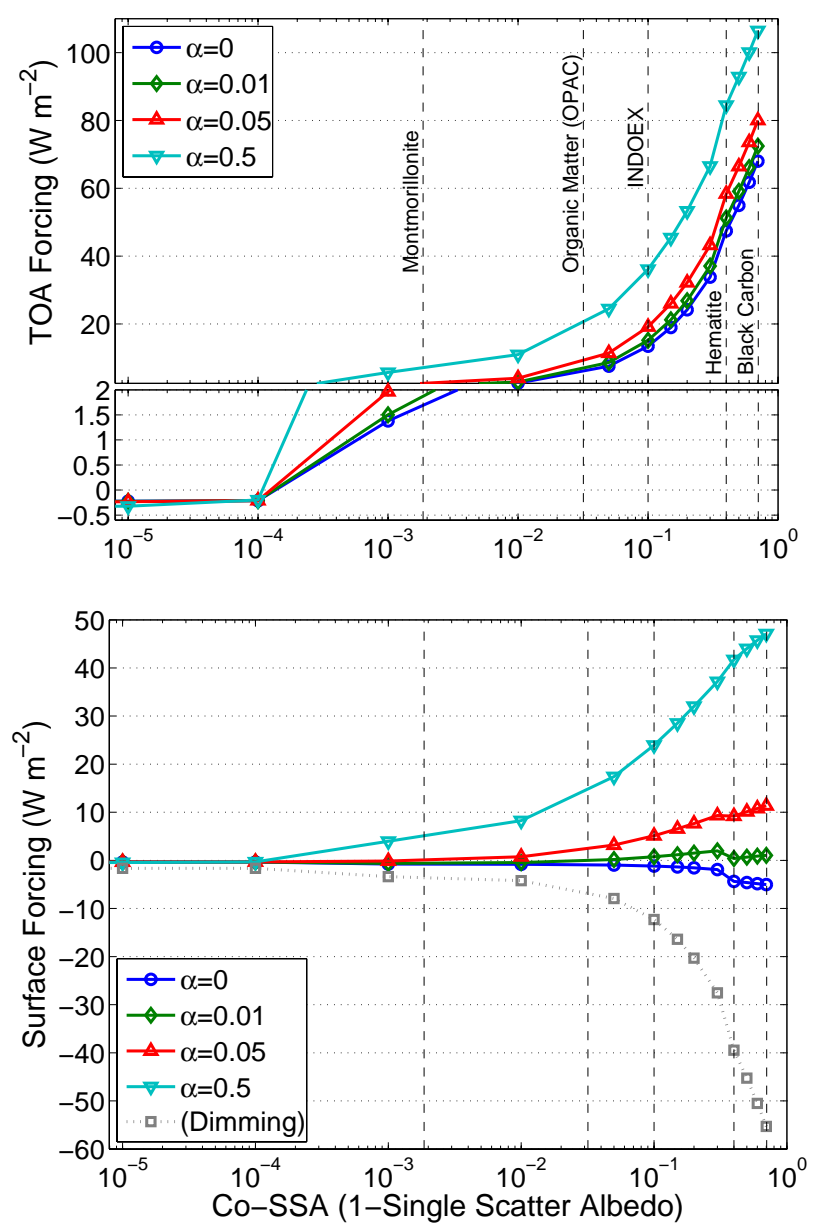

Fig. 1. Daily-mean (top) top-of-atmosphere and (bottom) surface changes in net solar power (forcing) as a function of single-scatter albedo complement (1-SSA) at $500 \mathrm{~nm}$. Extinction optical depth of the atmospheric aerosol is fixed at 0.2 and the environment represents a clear-sky atmosphere overlying snowpack with effective grain size of $200 \mu \mathrm{m}$ on 1 April at $45^{\circ} \mathrm{N}$. Curves are shown for different values of $\alpha$, the ratio of particle mixing ratio in snow to atmospheric column burden. Forcings represent the combined influence of particles in the atmosphere and snow. For reference, the change in downwelling surface insolation ("Dimming") is also depicted. Vertical lines depict common SSA values of black carbon, organic matter, and that measured during the Indian Ocean Experiment (INDOEX) (Ramanathan et al., 2001). Also shown are SSA values of strongly and weakly absorbing components of dust aerosols.

lofted over snow, in spite of negative forcings averaged over all area (Pfister et al., 2008; Stone et al., 2008). However, it is commonly assumed that any aerosol mixture produces negative surface forcing, raising the importance of our conclusion that small particle mixing ratios in snow reverse the sign of this term. 
Table 2. Equilibrium climate changes.

\begin{tabular}{|c|c|c|c|c|c|}
\hline Case & Effect & $\begin{array}{c}\text { EA / NA Spring }{ }^{\mathrm{a}} \\
\text { Snow Cover }\left(10^{6} \mathrm{~km}^{2}\right)\end{array}$ & $\begin{array}{l}\text { EA / NA Max } \\
\text { Melt Date }\end{array}$ & $\begin{array}{l}\text { EA / NA Spring } \\
\text { Sfc. Temp. }\left({ }^{\circ} \mathrm{C}\right)\end{array}$ & $\begin{array}{c}\text { Global Ann. Sfc. } \\
\text { Temp. }\left({ }^{\circ} \mathrm{C}\right)\end{array}$ \\
\hline PI2-PI1 & $\mathrm{CO}_{2}$ increase & $-1.79^{*} /-0.54^{*}$ & $-3.7 /-0.0$ & $+1.55^{*} /+0.77^{*}$ & $+0.89^{*}$ \\
\hline PI3-PI1 & $\mathrm{BC}+\mathrm{OM}$ in atmos. & $-0.34 /-0.08$ & $-2.2 /+3.5$ & $+0.26 /-0.25$ & -0.02 \\
\hline PI4-PI1 & $\mathrm{BC}+\mathrm{OM}$ in snow & $-1.52^{*} /-0.36^{*}$ & $-5.3^{*} /-1.4$ & $+0.61^{*} /+0.39$ & $+0.08^{*}$ \\
\hline PI5-PI1 & $\mathrm{BC}+\mathrm{OM}$ in atmos. + snow & $-1.70^{*} /-0.21$ & $-7.3^{*} /-1.5$ & $+0.93 * /-0.15$ & +0.04 \\
\hline PI6-PI1 & above $+\mathrm{CO}_{2}$ increase & $-2.96 * /-1.03^{*}$ & $-9.0^{*} /-6.7^{*}$ & $+2.06^{*} /+1.52^{*}$ & $+1.07^{*}$ \\
\hline PD2-PD1 & $\mathrm{FF}+\mathrm{BF} \mathrm{BC}+\mathrm{OM}$ in $\mathrm{PD}$ & $+0.97^{*} /+0.19$ & $+1.3^{*} /+4.7$ & $-0.36 /-0.26$ & $-0.07^{*}$ \\
\hline \multicolumn{6}{|c|}{ Absolute values from control simulations } \\
\hline PI1 & - & $20.5 / 10.9$ & $114 / 121^{\mathrm{d}}$ & $-0.6 /-2.4$ & 12.9 \\
\hline PD1 & - & $16.6 / 9.5$ & $103 / 111$ & $+1.9 /-0.5$ & 14.4 \\
\hline
\end{tabular}

${ }^{\text {a }}$ Eurasia/North America March-May snow-covered area.

b Spatially averaged $\left(30-66.5^{\circ} \mathrm{N}\right)$ central date of 31-day period of maximum snow melt.

${ }^{\mathrm{c}}$ Eurasia/North America land-averaged (north of $30^{\circ} \mathrm{N}$ ) March-May surface temperature.

d Julian day.

* Statistically significant at the 0.05 level.

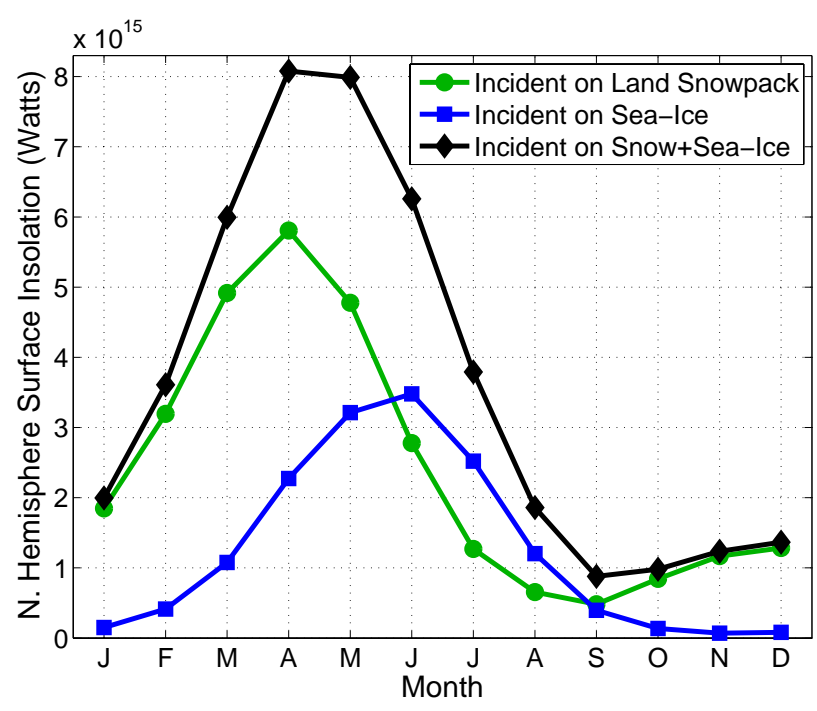

Fig. 2. Northern Hemisphere surface insolation incident upon landbased snow and sea-ice, as a function of month. Data are derived from 1990's mean snow and ice extent (Armstrong and Brodzik, 2005) and assimilated surface insolation (Qian et al., 2006). Insolation on land snowpack peaks in March-May, when continental snow-albedo feedback is strongest.

\subsection{Equilibrium climate response}

Results discussed above suggest that absorbing particles can exert a strong positive energy forcing, both at the surface and top-of-atmosphere (TOA), when lofted over, and deposited to snowpack subject to modest insolation. Figure 2 depicts the 1990's mean annual-cycle of Northern Hemisphere insolation incident on land-based snowpack. This figure shows a peak during boreal spring (March-May), when a large portion of extratropical land is snow-covered and mid-latitude insolation is relatively intense. Hence, changes in snow reflectance and cover exert the greatest influence on Earth's energy budget during spring, consistent with research showing April-May to be the time of maximum snow-albedo feedback (Hall and Qu, 2006). Here we examine the isolated and combined springtime climate impacts of carbonaceous particles in both the atmosphere and snow, in comparison with response to $\mathrm{CO}_{2}$-induced warming.

Table 2 summarizes equilibrium changes in snow covered area (SCA), date of maximum snow melt rate, springtime continental surface temperature, and global annual-mean surface temperature for experiments described in Table 1. A key result is that Eurasian springtime SCA decreases by a comparable amount (95\% as great) from fossil fuel and biofuel (FF+BF) emissions of $\mathrm{BC}+\mathrm{OM}$ (PI5-PI1) as from $\mathrm{CO}_{2}$ (PI2PI1). Moreover, large SCA reductions are simulated when carbonaceous particles are active in snow (PI4-PI1), but not when active exclusively in the atmosphere (PI3-PI1). This follows from darkening being the dominant surface forcing term over snow (discussed later). Reductions in SCA caused by $\mathrm{BC}+\mathrm{OM}$ are greater over Eurasia than North America, where changes are not significant at the 0.05 level. Different continental responses are expected because of greater aerosol loading and forcing over Eurasia, where emissions are greater (Bond et al., 2004). BC+OM aerosol optical depths averaged over Eurasia and North America are 0.011 and 0.0058 , respectively, in experiment PI5. Figure 3 depicts the geographic distribution of changes in springtime snow cover for these experiments. The largest changes induced by $\mathrm{BC}+\mathrm{OM}$ occur over the Tibetan Plateau (where surface insolation is intense), Eastern Asia, and Eastern Europe, whereas 

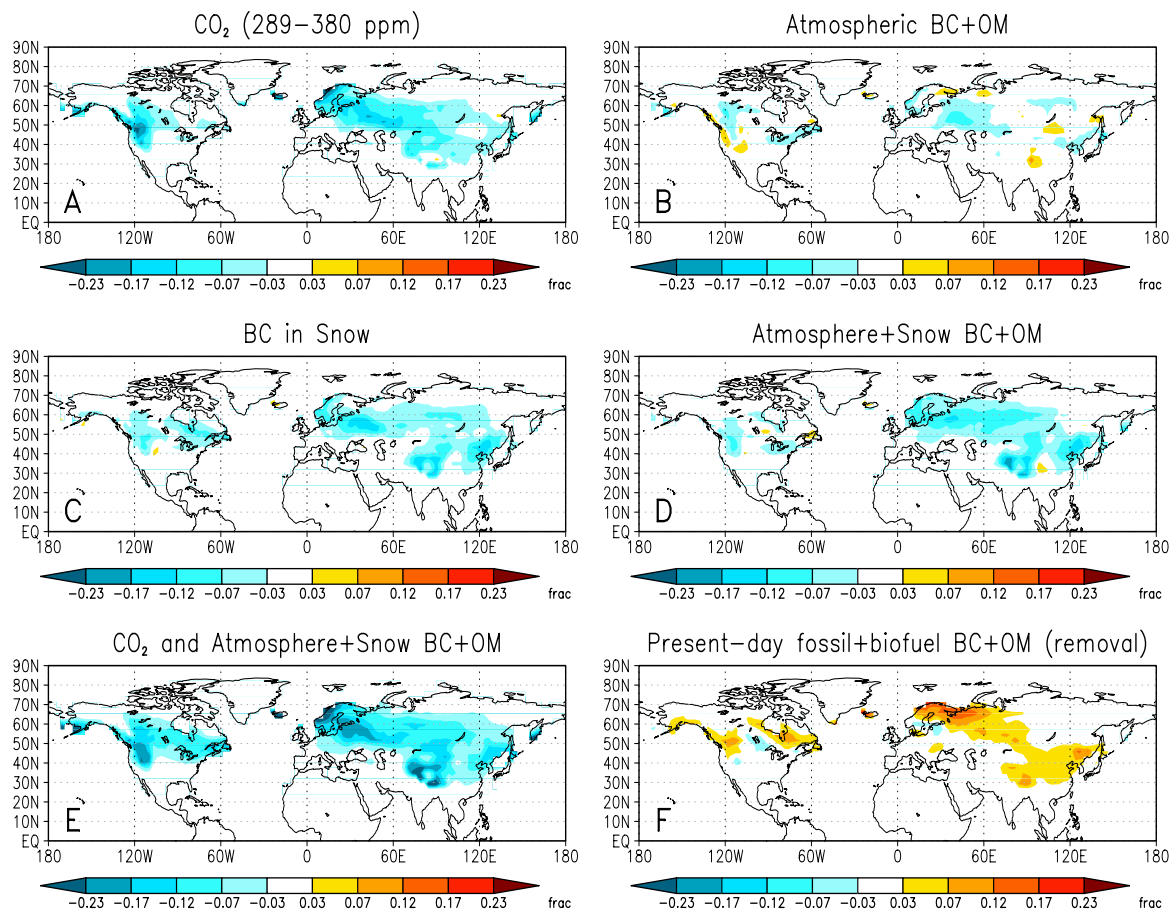

Fig. 3. Equilibrium changes in March-May snow cover fraction resulting from the following forcing mechanisms (also see Table 1): (A) $\mathrm{CO}_{2}$ only (experiment PI2-PI1), (B) black carbon (BC) and organic matter (OM) in the atmosphere only (PI3-PI1), (C) BC in snow only (PI4-PI1), (D) $\mathrm{BC}+\mathrm{OM}$ in the atmosphere and snow (PI5-PI1), (E) $\mathrm{CO}_{2}$ and $\mathrm{BC}+\mathrm{OM}$ in the atmosphere and snow (PI6-PI1), and (F) removal of all fossil fuel and biofuel emissions of $\mathrm{BC}+\mathrm{OM}$ (active in the atmosphere and snow) from present climate (PD2-PD1). Continental averages of these changes are listed in Table 2.

$\mathrm{CO}_{2}$-induced reductions are greatest over Eastern and Northern Europe and Western North America.

Table 2 also lists the area-averaged change in peak snowmelt date, expressed as the central date of the 31day period experiencing maximum melt (calculated at each gridcell). The results show statistically-significant earlier peak snowmelt of 5 and 7 days from snow-only and atmosphere+snow $\mathrm{BC}+\mathrm{OM}$ forcing, respectively, averaged over mid-latitude $\left(30-66.5^{\circ} \mathrm{N}\right)$ Eurasia. The peak melt rate over North America is unaffected by $\mathrm{CO}_{2}$-only and $\mathrm{BC}+\mathrm{OM}-$ only forcings, but these two agents combine to shift peak snowmelt 7 days earlier (PI6-PI1).

Equilibrium temperature changes are consistent with SCA changes. Statistically-significant warming of $1.55,0.93$, and $2.06^{\circ} \mathrm{C}$ occurs over springtime Eurasia under the influences of, respectively, $\mathrm{CO}_{2}, \mathrm{BC}+\mathrm{OM}$, and their combined effects. Warming from atmospheric $\mathrm{BC}+\mathrm{OM}$ is not statistically significant. This small warming is consistent with Hansen et al. (2005), who cite a low efficacy for atmospheric BC+OM because of negative feedback caused by low cloud formation.

We also assess the consequences of eliminating $\mathrm{FF}+\mathrm{BF}$ $\mathrm{BC}+\mathrm{OM}$ emissions from present-day climate (PD2-PD1). Both of these simulations include biomass burning particles and mineral dust in the atmosphere and snow. This configuration produces slightly smaller radiative forcing because of increased extinction from other species, but also a more realistic approximation of the $\mathrm{FF}+\mathrm{BF}$ particle influence on present climate. With removal of $\mathrm{FF}+\mathrm{BF} \mathrm{BC}+\mathrm{OM}$, Eurasian springtime SCA expands by 1 million $\mathrm{km}^{2}$, or $25 \%$ of the change from PI1 to PD1. Springtime Eurasia cools by $0.36^{\circ} \mathrm{C}$, less than the influence of atmosphere+snow $\mathrm{BC}+\mathrm{OM}$ on pre-industrial climate (PI5-PI1), and a likely consequence of less snow cover in the PD1 control simulation. Global, annual-mean surface temperature cools by $0.07^{\circ} \mathrm{C}$ (significant at $p=0.05)$. This signal is smaller than the $0.20^{\circ} \mathrm{C}$ surface temperature response reported by Jacobson (2004), who also included the effect of snow darkening. Possible contributors to this difference include smaller radiative forcing in our study, different thermal-infrared water vapor and cloud feedbacks, and inherent model variability.

Table 3 lists area-averaged radiative forcing components from these experiments, building on analysis of column results and helping explain the climate responses. Shown are surface forcings averaged only over snow (i.e., the change in absorbed solar energy by snowpack) caused by surface darkening and dimming from $\mathrm{FF}+\mathrm{BF} \mathrm{BC}+\mathrm{OM}$, and globallyaveraged TOA forcings. Over global snow cover, annual forcing from darkening exceeds the counteracting forcing from dimming by a factor of about 6 (experiment PI6). In addition to explanations provided above, this occurs because 
Table 3. Radiative Forcings $\left(\mathrm{W} \mathrm{m}^{-2}\right)$

\begin{tabular}{lcccccc}
\hline & $\begin{array}{c}\text { Global } \\
\text { Snow } \\
\text { Carkening }\end{array}$ & $\begin{array}{c}\text { Global } \\
\text { Snow } \\
\text { Dimming }^{\mathrm{a}}\end{array}$ & $\begin{array}{c}\text { EA/NA } \\
\text { Spring Snow } \\
\text { Darkening }^{\mathrm{b}}\end{array}$ & $\begin{array}{c}\text { EA/NA } \\
\text { Spring Snow } \\
\text { Dimmingc }^{\mathrm{c}}\end{array}$ & $\begin{array}{c}\text { Global TOA } \\
\text { Snow } \\
\text { Darkening }\end{array}$ & $\begin{array}{c}\text { Global TOA } \\
\text { Atmospheric } \\
\text { BC+OM }^{\mathrm{d}}\end{array}$ \\
\hline PI3 & 0 & -0.11 & $0 / 0$ & $-0.33 /-0.18$ & 0 & +0.21 \\
PI4 & +0.70 & 0 & $+3.02 /+1.26$ & $0 / 0$ & +0.057 & 0 \\
PI5 & +0.68 & -0.11 & $+3.00 /+1.23$ & $-0.32 /-0.18$ & +0.056 & +0.21 \\
PI6 & +0.61 & -0.10 & $+2.81 /+1.10$ & $-0.31 /-0.16$ & +0.048 & +0.21 \\
\hline
\end{tabular}

a Global, annual-mean surface radiative forcing averaged only over snow.

${ }^{\mathrm{b}}$ Eurasia / North America March-May surface radiative forcing averaged only over snow.

c Top-of-atmosphere radiative forcing from black carbon in snow, averaged annually and over all global surface.

$\mathrm{d}$ Top-of-atmosphere radiative forcing from atmospheric $\mathrm{BC}+\mathrm{OM}$, averaged annually and over all global surface.
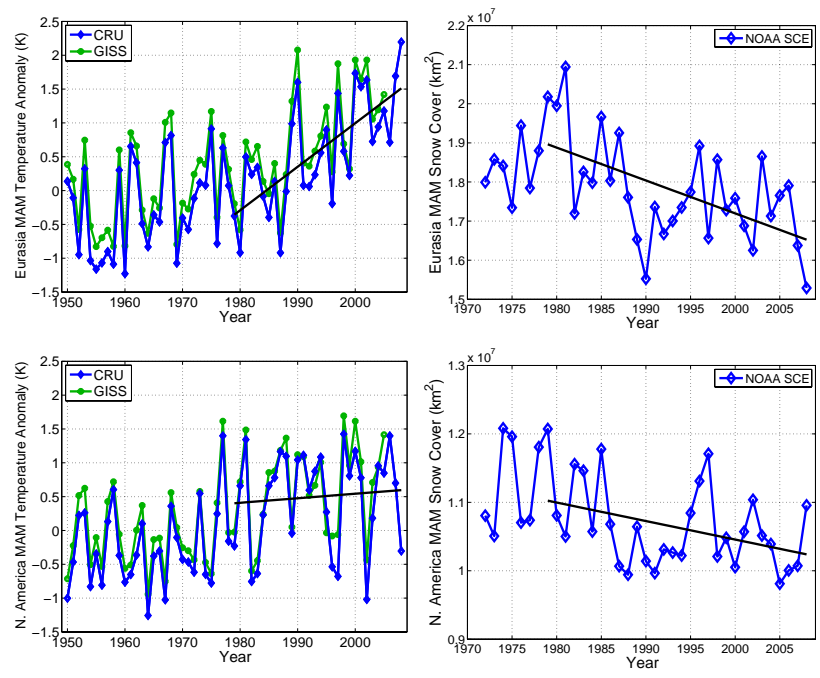

Fig. 4. Timeseries of observed springtime (March-May) temperature anomalies (averaged over land north of $30^{\circ} \mathrm{N}$ ) and snow cover extent over Eurasia and North America . Temperature data are from CRUTEM3 (Brohan et al., 2006) and NASA GISS (Hansen et al., 2001). Anomalies are relative to different mean periods, explaining the slight offset between GISS and CRUTEM3 data. Snow cover extent is from NOAA/Rutgers (Robinson and Frei, 2000). Linear trends are shown for 1979-2008 data.

$\mathrm{BC}$ persists longer in near-surface snow than it does in the atmosphere. This is particularly true during spring melt, when hydrophobic BC can accumulate near the snow surface (Conway et al., 1996; Flanner et al., 2007), and also when impurities exert a large forcing because of intense insolation. This also explains why darkening/dimming forcing ratios are greater in spring than in the annual mean (Table 3). Global TOA forcing from atmospheric $\mathrm{BC}+\mathrm{OM}$ is positive, and exceeds that from snow darkening by a factor of 4 (experiment PI6), when averaged over all global surface. Springtime net (dimming+darkening) snow surface forcings from $\mathrm{BC}+\mathrm{OM}$ are 2.5 and $0.9 \mathrm{~W} \mathrm{~m}^{-2}$, averaged over Eurasia and
North America, respectively (experiment PI6). This compares with a global-mean forcing of about $1.5 \mathrm{~W} \mathrm{~m}^{-2}$ for a change in $\mathrm{CO}_{2}$ concentration of 289-380 ppm (Myhre et al., 1998).

Our global forcing estimate for atmospheric BC (including biomass sources) is only about one-third of a recent estimate of $0.9 \mathrm{~W} \mathrm{~m}^{-2}$ (Ramanathan and Carmichael, 2008). One likely reason for low model forcing in this study is failure to loft BC above low clouds, particularly in the tropics where absorbing particles exert large forcing. Peak aerosol absorption was measured at $2 \mathrm{~km}$ elevation over the Indian Ocean (Ramanathan et al., 2007), with large aerosol loading extending to $3 \mathrm{~km}$. A second reason is lack of "brown carbon" aerosol components which absorb strongly at wavelengths less than $400 \mathrm{~nm}$. As mentioned in methods, we account for absorption enhancement by internally-mixed BC, often considered a third factor in model underprediction of BC forcing (Jacobson, 2001; Ramanathan and Carmichael, 2008). Discrepancies in forcing estimates nonetheless illustrate the large uncertainty persisting with aerosol forcing, and also suggest that $\mathrm{BC}$ warming effects may be significantly underestimated in this study.

\subsection{Recent observed and simulated springtime climate trends}

We showed in the previous section that springtime climate response to carbonaceous aerosols is greater over Eurasia than North America. During the last 30 years, springtime climate has warmed rapidly over mid- and high-latitude Eurasia. Furthermore, we will show that climate models almost universally underpredict Eurasian springtime warming and snow cover decline. In this section we explore the extent to which snow darkening from deposition of black carbon and mineral dust, processes lacking in modern climate models, can reconcile these discrepancies.

Figure 4 depicts observed Eurasia and North America March-May (MAM) land surface temperature and snow cover timeseries. Springtime land north of $30^{\circ} \mathrm{N}$ 

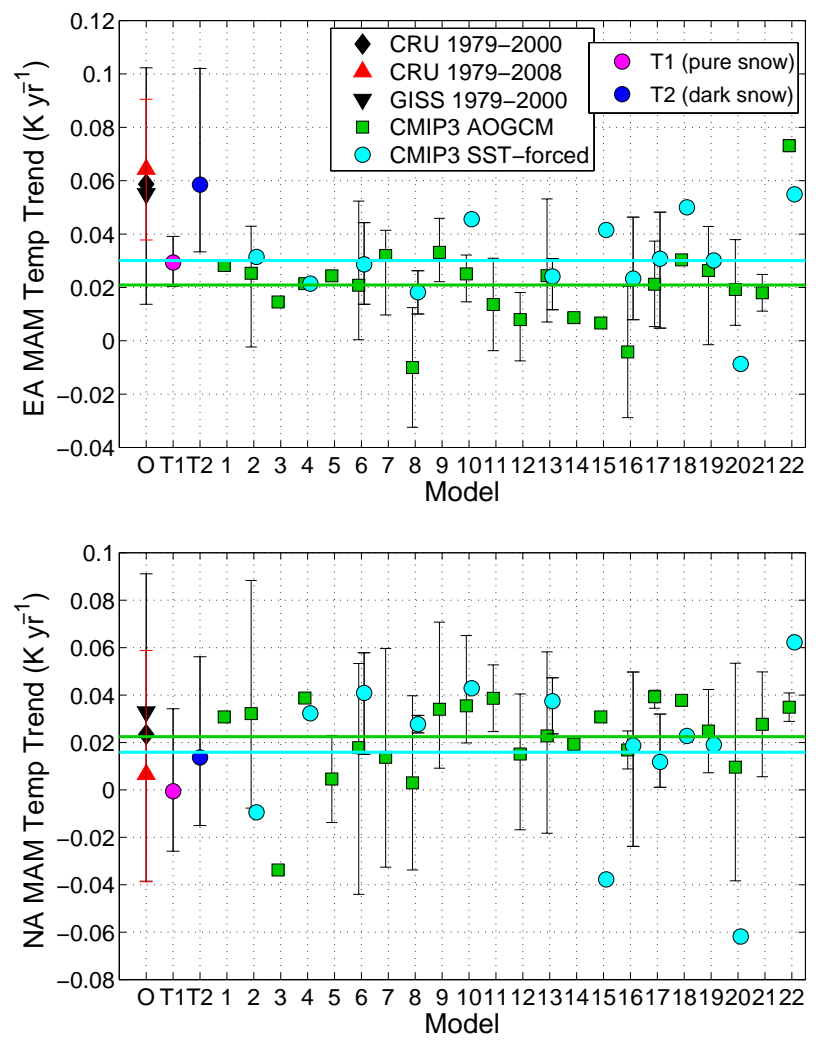

Fig. 5. Linear trends in (top) Eurasian and (bottom) North American land-averaged (north of $30^{\circ} \mathrm{N}$ ) March-May surface air temperatures. Observations from CRUTEM3 and NASA GISS are shown on the left-most vertical bar. 1979-2000 trends from 5-member, SST-forced ensemble experiments without (purple) and with (blue) snow darkening from black carbon and mineral dust are shown above labels "T1" and "T2". Trends from AOGCM (green) and SST-forced (light blue) models contributing to CMIP3 and the IPCC AR4 are above labels "1-22" and described in Appendix A. Horizontal color-coded lines depict means from these two groups of models. Interval bars represent the full range of trends from all available ensemble members. Note that only 13 groups submitted SST-forced simulations, some simulations extend only through 1999, and number of ensemble members varies considerably (Appendix A). The brackets associated with observations depict $95 \%$ confidence intervals of trends, derived with the Mann-Kendall and Theil-Sen techniques.

warmed at a rate of $0.64(0.59)^{\circ} \mathrm{C}$ decade $^{-1}$ during 1979 2008 (1979-2000) over Eurasia, compared with only 0.07 $(0.23)^{\circ} \mathrm{C} \mathrm{decade}^{-1}$ over North America. Linear trends in observed snow cover extent (SCE) suggest that Eurasia and North America lost 13.5 and 6\%, respectively, of their 19681978 mean MAM snow cover during 1979-2008 (also see Déry and Brown, 2007). These trends are significant at $p=0.05$ over Eurasia, but not over North America. Eurasia also experienced the warmest spring and least snow cover on record during 2008.
Hindcasts of 1979-2000 springtime temperature and snow cover trends by SST-forced and AOGCM models contributing to CMIP3 and the IPCC AR4 are shown in Figs. 5 and 6 , along with observed trends. Most SST-forced experiments begin in 1979, with the onset of remotely-sensed sea-ice distributions, and hence our comparison also begins with this year. Also shown are trends from transient simulations T1 and T2 (Table 1), SST-forced ensembles we conducted without and with snow darkening, respectively.

All 13 SST-forced models, and 21 of 22 AOGCMs under-predict observed Eurasian springtime warming, while half of these models over-predict North American warming (Fig. 5). The CMIP3 model-mean Eurasian warming trend is $0.024^{\circ} \mathrm{C} \mathrm{yr}^{-1}$, less than half of that observed. Moreover, models tend to predict similar trends over both continents. The mean difference (Eurasia-North America) in simulated continental trends is $+0.004^{\circ} \mathrm{C} \mathrm{yr}^{-1}$, compared with the observed difference of $+0.035^{\circ} \mathrm{C} \mathrm{yr}^{-1}$ (or $+0.058^{\circ} \mathrm{C} \mathrm{yr}^{-1}$ from 1979-2008). Only one AOGCM experiment (conducted with the UK HadGEM model) over-predicts Eurasian warming. Figure 6 shows that all models underpredict Eurasian spring snow cover decline. Interestingly, models also tend to underpredict North American snow loss, although less severely. The GISS-ER model did include a parameterized BC-albedo effect (Hansen et al., 2007), but trends from this model were similar to mean CMIP3 trends.

Amplified warming and ubiquitous model biases over springtime Eurasia suggest that a forcing or warming mechanism which operates more strongly over Eurasia is absent in current models. Inclusion of snow darkening in ensemble experiment $\mathrm{T} 2$ introduces a mean surface forcing over springtime Eurasian snow $\left(3.9 \mathrm{~W} \mathrm{~m}^{-2}\right)$ more than three-fold greater than over North American snow $\left(1.2 \mathrm{~W} \mathrm{~m}^{-2}\right)$, averaged from 1979-2000. Contributions from mineral dust to these estimates are 1.2 and $0.2 \mathrm{~W} \mathrm{~m}^{-2}$, respectively, and the geographic patterns of these forcing are shown in Fig. 7. The additional source of energy to snowpack drives earlier melt on the southern boundary of snow extent, reducing Eurasia springtime snow cover by $10 \%$ (significant at $p=0.001$ ). This snow cover reduction may enable elevated rates of midand high-latitude warming. Relative to the T1 control ensemble, Eurasian springtime warming accelerates from 0.35 to $0.61^{\circ} \mathrm{C} \mathrm{decade}^{-1}$ (significant at $p=0.05$ ), whereas changes over North America are smaller, but still represent an improvement (Fig. 5).

Geographic patterns of observed and simulated springtime temperature trends are shown in Fig. 8. The spatial pattern of warming is improved with inclusion of snow darkening, particularly over Northern Asia, where control simulations (T1) predict a cooling trend but observations show strong warming. The $\mathrm{T} 1$ cooling signal is striking, given that sea-ice and SST distributions were prescribed, and may indicate that recent temperature trends over this land region are more strongly influenced by processes to the south, rather than sea-ice to the north. Snow darkening does not reduce 

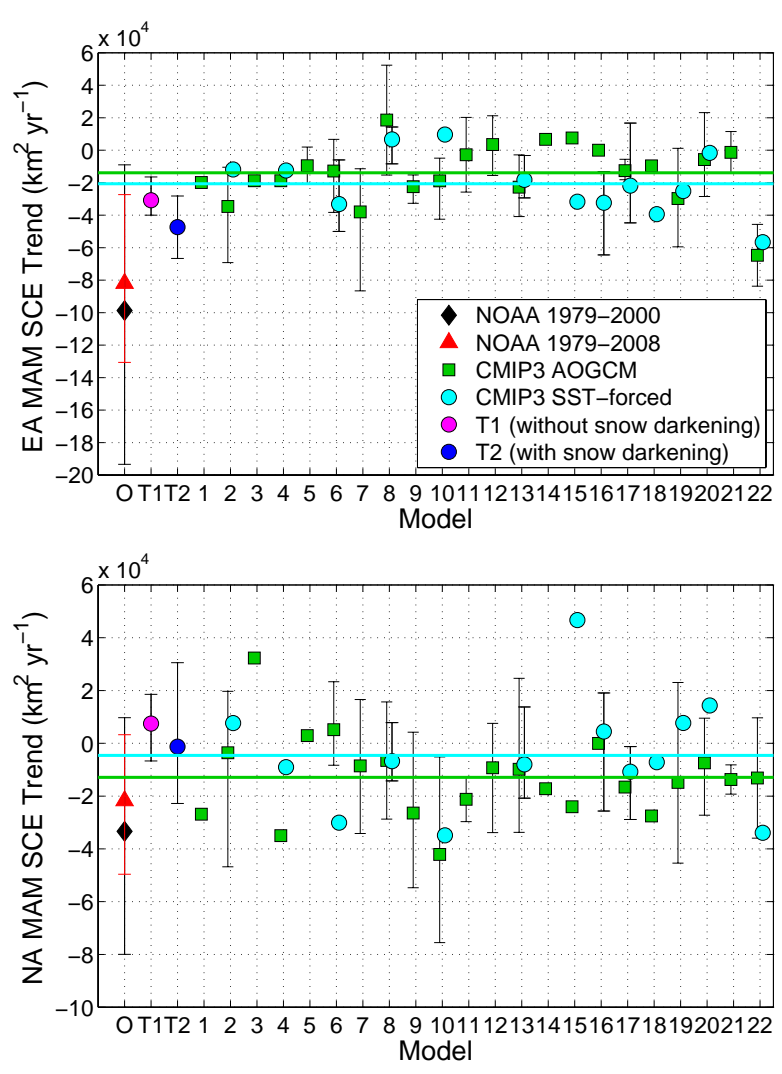

Fig. 6. Linear trends in (top) Eurasian and (bottom) North American snow cover extent. Observations from NOAA/Rutgers are shown on the left-most vertical bar. The format of this figure is otherwise identical to Fig. 5.

MAM snow cover in this high-latitude region, as it remains too cold, but snow reductions further south may enable advection of warmer air. The temperature trend reversal in this region could also be due to dynamical or cloud feedbacks. Model biases persisting with snow darkening include cooling in the Canadian Arctic Archipelago and excessive warming over Western Asia.

Figure 8 also depicts geographic patterns of simulated trends in spring snow cover and January-May BC deposition. Snow cover declines slightly more rapidly over much of Asia when snow darkening is included. However, BC deposition trends are negative or near-neutral over large parts of Western, Central, and Northern Asia (Fig. 8). Although Asian fossil+biofuel BC emissions increased by $50 \%$ during the transient duration (Bond et al., 2007), positive deposition trends are constrained mostly to Eastern and Southern Asia. Because the control ensemble (T1) prescribed no snow darkening, rather than constant darkening, comparison of these experiments reveals influences of both absolute darkening and changes in darkening. These results may suggest that a certain degree of baseline darkening, and associated mean snow cover reduction, are as important for temperature
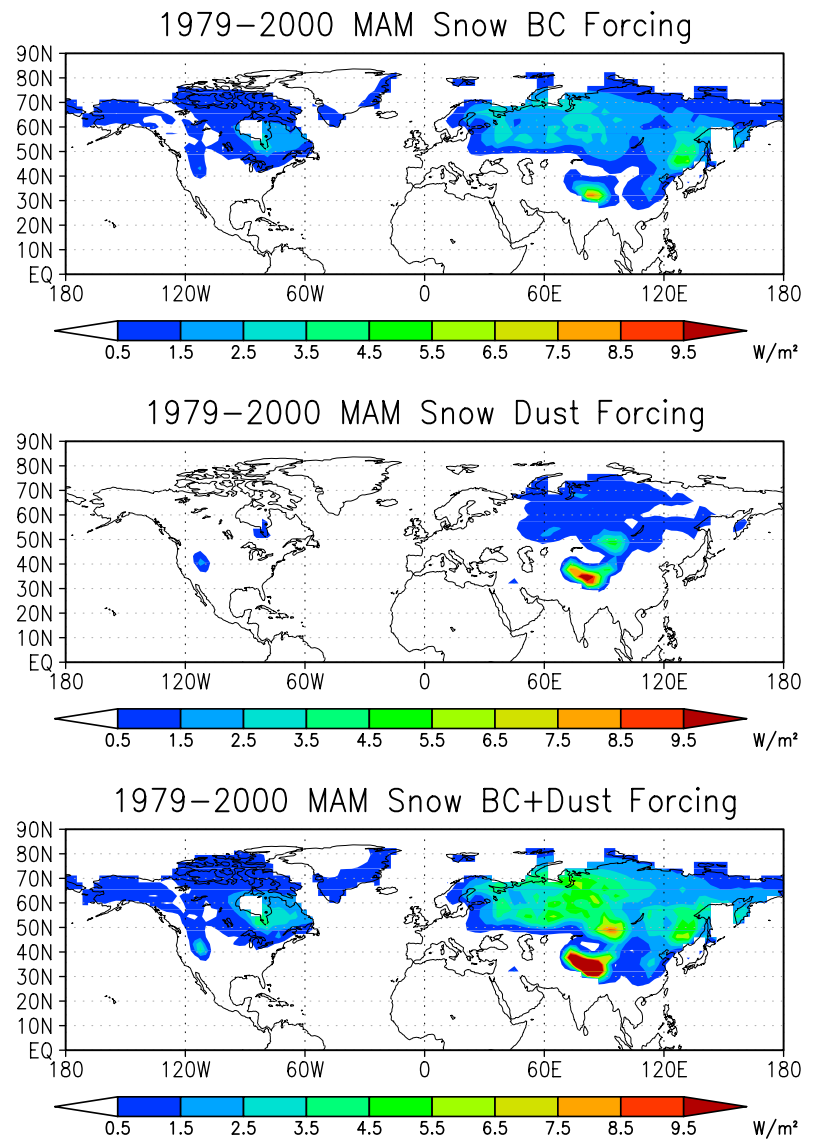

Fig. 7. March-May surface radiative forcing, averaged spatially and temporally only over snow, caused by (top) black carbon in snow, (middle) mineral dust in snow, and (bottom) both agents. Data are 1979-2000 ensemble means from experiment T2 (Table 1).

change as the trends in darkening resulting from 1979-2000 deposition changes. Figure 7 does show rather large mean radiative forcing on snow in Central Asia, caused by $\mathrm{BC}$ and mineral dust. Additional simulations, applying an AOGCM with varying degrees of darkening, are needed to address this issue more comprehensively. Over Europe and North America, fossil+biofuel BC emissions decreased by $20 \%$ and $8 \%$, respectively, during 1980-2000 (Bond et al., 2007), while simulated emissions of mineral dust and biomass burning BC exhibited no significant trend over either continent.

Other possible support for a snow darkening role in model snow cover biases comes from an analysis by Frei et al. (2003) of 1979-1995 SCE predictions in SST-forced models. This study found universal high biases in modeled December-March SCE over Eastern Asia and the Tibetan Plateau, two regions we find to be strongly affected by snow darkening (Figs. 3 and 7), and also concluded that magnitudes of the biases in these regions were not correlated with magnitudes of either temperature or precipitation biases. Tibetan Plateau SCE biases are also caused, however, 

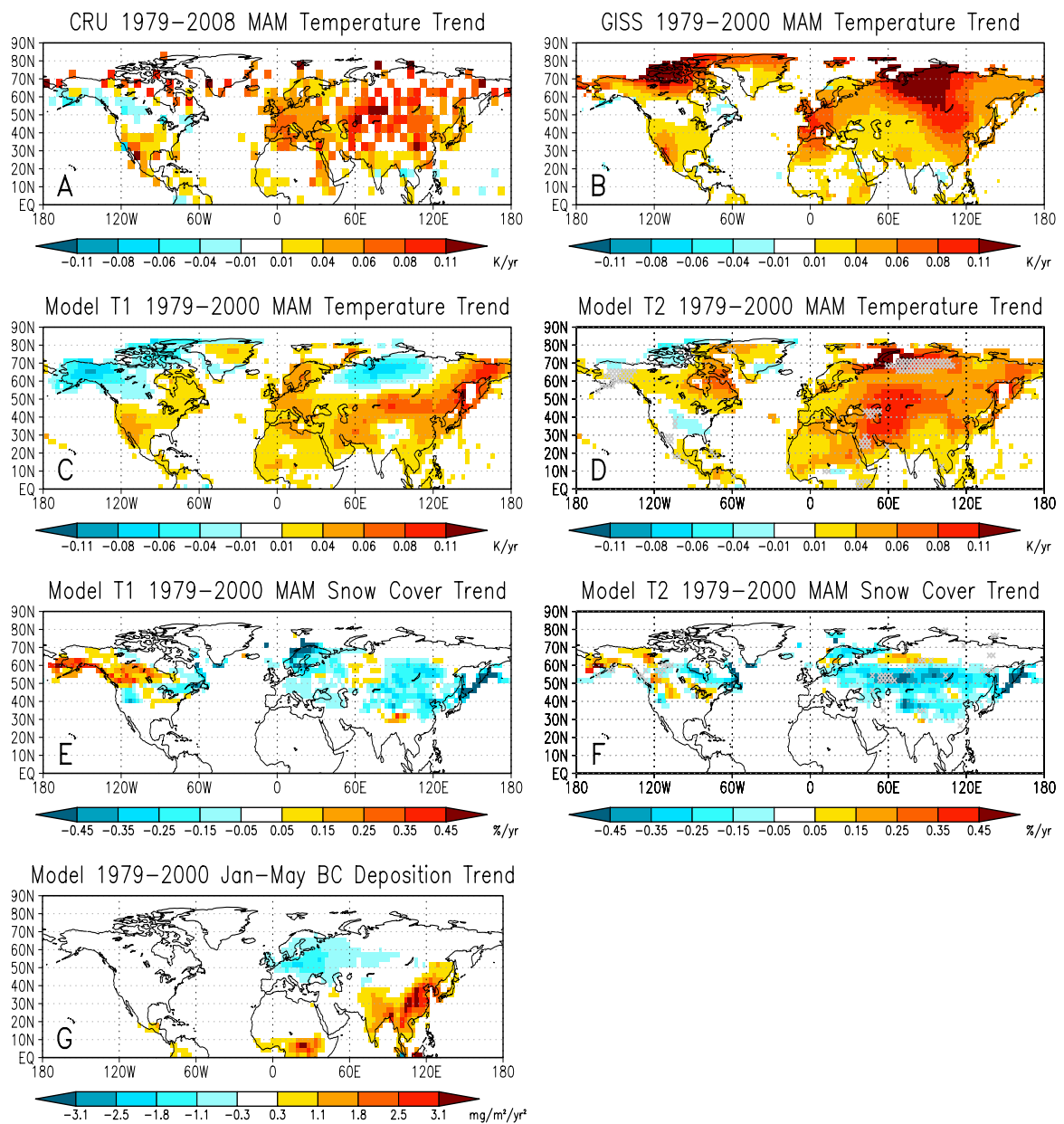

Fig. 8. Geographic distributions of springtime surface temperature, snow cover, and black carbon deposition trends. Panels depict MarchMay trends in (A) 1979-2008 CRUTEM3 surface temperature observations, (B) 1979-2000 NASA GISS temperature analysis, 1979-2000 ensemble-mean surface temperature from experiments (C) without snow darkening and (D) with snow darkening from deposition of black carbon and mineral dust, and snow cover fraction (E) without and (F) with snow darkening. (G) shows January-May black carbon deposition trends simulated in experiment T2, using historical emissions (Bond et al., 2007, and outlined in methods). Grey stippling in panels (D) and $(\mathrm{F})$ indicates regions where trends are statistically different $(p=0.05)$ from those of the T1 ensemble.

by unresolved vertical penetration of solar radiation, which induces sub-surface melt in low-latitude snowpack (Flanner and Zender, 2005).

Although snow darkening reduces Eurasian springtime snow cover and drives faster warming, it only marginally improves simulated SCE trend, relative to NOAA observations (Fig. 6). Figure 9 shows that model springtime trends in temperature and snow cover are highly correlated $(r=0.77$ and 0.82 over Eurasia and North America, respectively), but this relationship does not agree with 1979-2000 observations, which show a much greater ratio of snow cover decline to warming. Models are closer to the 1979-2008 observed SCE/temperature trend ratio, but still smaller. This reinforces the caution that should be exercised in assessing trends of data with high frequency variability, but may also suggest that the relationship between SCE and temperature trends is not robust, even on decadal timescales. Interestingly, the SCE/temperature change ratio from some of our equilibrium experiments (e.g., PI5-PI1) are much closer to the observed ratio, as shown in Fig. 9a. One explanation for this is the greater snow coverage, and hence potential for snow removal, in the initial states of the PI simulations.

Reduced winter snow accumulation (preceding spring melt onset) could also drive reduced spring snow cover, but observations do not support a dominant role for this effect. First, Déry and Brown (2007) show increasing (but not significant) 1972-2006 Eurasian SCE trends during all months from October to January, suggesting early-winter snow accumulation has, if anything, increased. (February SCE decreased, but not significantly.) Analysis of streamflow in watersheds of Western North America indicates that the onset of spring melt has shifted earlier since 1950, and that 

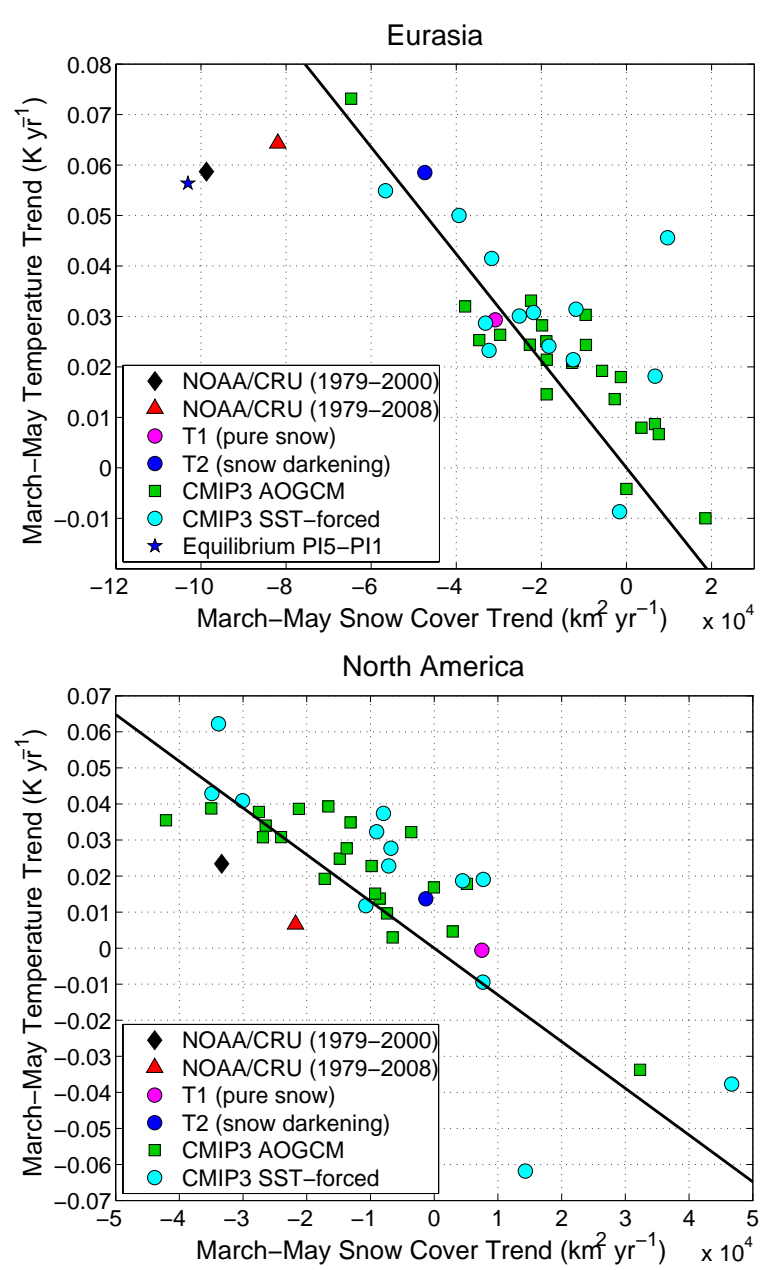

Fig. 9. 1979-2000 trends in springtime (March-May) surface temperatures (averaged over land north of $30^{\circ} \mathrm{N}$ ) versus corresponding trends in snow cover extent (SCE) for Eurasia (top) and North America (bottom). Data are shown for observations (CRUTEM3 temperatures and NOAA/Rutgers snow cover), AOGCM and SSTforced model data from CMIP3 (also depicted in Figs. 5 and 6), and our T1 and T2 experiments, without and with snow darkening, respectively. A datum is included showing equilibrium changes from experiment PI5-PI1 (Table 2). Because it is an equilibrium change, the position of this point is arbitrary along a line through the origin.

these trends are driven largely by winter and spring warming (Stewart et al., 2005). Finally, Pierce et al. (2008) found a decrease over the Western US (during 1950-1999) in the ratio of 1 April snow water equivalent to year-to-date precipitation. Our own assessment of January-May snowfall trends over 1979-2000 from re-analysis data (Qian et al., 2006) does show a significant decline in winter-spring snowfall over North America, but no significant change in Eurasian snow accumulation. We acknowledge large uncertainties in these data, however.
Some caveats and alternative explanations for model underprediction of Eurasian warming must be discussed. First, the CMIP3 SST-forced experiments generally do not include time-evolving greenhouse gas and aerosol forcing, whereas most AOGCM experiments do (although treatment of aerosol evolution is quite variable). Thus, reduced warming trend in SST-forced models does not necessarily point to a snow darkening role. It does, however, show that dynamic coupling between SST/sea-ice evolution and the land surface, alone, is insufficient to explain Eurasian springtime warming. Oceanic influence on interior Eurasia should be weakened because of continental size alone. Slow warming in the CMIP3 SST-forced simulations is also consistent with the Northern Eurasia trend bias found in ensemble T1. However, T1 does include time-evolving greenhouse gases and atmospheric aerosols. Therefore, this single set of experiments (T1 and T2) does support a role for snow darkening in driving amplified Eurasian springtime warming. Also, the influence of snow darkening on continental warming, via ocean warming, is not accounted for in these simulations because SSTs are prescribed. However, Northern Hemisphere MAM ocean temperatures warmed by only $+0.06^{\circ} \mathrm{C}$ in equilibrium experiment PI4-PI1, smaller than the transient 19792000 SST warming of $+0.21^{\circ} \mathrm{C}$, suggesting this indirect effect is small.

Other potential sources of model-observation trend differences include: 1) uncertainty in trend analysis, 2) inaccurate observational data, 3) sufficient biases in model forcing data (e.g., aerosol distributions) to prevent rapid continental warming and/or snow cover decline, and 4) poor representation, in all models, of atmospheric and/or surface processes that critically effect multi-year trends, including the influence of climate patterns like the North Atlantic Oscillation (NAO).

First, SST/sea-ice forcing data and homogeneous SCE observations only extend back to 1979 , hampering trend analysis because of large interannual variability. This is reflected by the large $95 \%$ confidence intervals bracketing observations in Figs. 5 and 6. Intervals are more confined in the 1979-2008 analysis, lending confidence that the climate trends are real, but model-observation comparison is currently restricted to 1979-2000, the years simulated by SSTforced CMIP3 models. Trends are also inherently sensitive to the period chosen for analysis. For example, North American springtime warming trends beginning in 1950 are greater than those beginning in 1979, owing to a transition that occurred around 1977 (Fig. 4), and Eurasian SCE decline rate is significantly slower over 1972-2006 (Déry and Brown, 2007), as can be seen in Fig. 4.

Second, although NOAA data are considered the most accurate and consistent observations of continental-scale SCE (Frei et al., 2003), studies suggest that springtime snow cover may be overestimated in mountainous regions (Déry and Brown, 2007) and Northern Canada (Wang et al., 2005). While absolute SCE may be biased in some regions, validity of multi-year continental-scale trends remains uncertain. 
Temperature anomalies, on the other hand, are more constrained, evidenced by close agreement between the CRU and GISS data (Fig. 4). Gridded station-based CRU data cover about $70 \%$ of the land area north of $30^{\circ} \mathrm{N}$ during our period of analysis.

Third, there are uncertainties in forcing data and mechanisms, particularly with aerosols. Much of this is associated with model representation of aerosol aging, optical properties, transport, vertical distribution, and interaction with clouds (e.g., Jacobson, 2001; Chung et al., 2005; Ramanathan and Carmichael, 2008; Shindell et al., 2008). Furthermore, the magnitude of snow darkening is sensitive to snow grain size, particle optical properties, and meltwater removal of particles; issues which compound to produce a large uncertainty range in global forcing estimates (Flanner et al., 2007). Historical emission inventories are also uncertain (Bond et al., 2007). For example, Sahu et al. (2008) estimate $2001 \mathrm{FF}+\mathrm{BF} \mathrm{BC}$ emissions from India of $1.34 \mathrm{Tg} \mathrm{yr}^{-1}$, compared with our inventory of $0.48 \mathrm{Tg} \mathrm{yr}^{-1}$. Also, as mentioned earlier, we neglect the role of absorbing "brown carbon", which may be further darkening snowpack in Asia and elsewhere.

Fourth, patterns like the NAO can exert large influence on decadal-scale climate trends (e.g., Hurrell et al., 2001). However, NAO phase and amplitude variability over the last half century are simulated well in SST-forced GCM ensembles (e.g., Rodwell et al., 1999). It is also possible that surface processes, such as snow - vegetation interaction, or atmospheric processes controlling ocean - land coupling are universally biased towards slow interannual snow ablation. A potentially related feature is the bias in CMIP3 models towards delayed spring melt (Roesch, 2006). (This conclusion has been contested, however, by Brown and Frei, 2007). Further study is also needed into why the HadGEM model predicts larger, more realistic springtime warming trends.

Finally, it is important to remember that different aerosol forcing trends are operating in different regions (Fig. 8g). Ruckstuhl et al. (2008) attribute recent, rapid European warming to reduced aerosol loading and surface brightening. Indeed, annual-mean net aerosol forcing is negative, and both sulfate-precursor and carbonaceous particle emissions from Europe have declined significantly since 1980 (Smith et al., 2001; Bond et al., 2007). However, springtime climate has warmed at a comparable, or more rapid rate over Eastern Asia (Fig. 8a, b), where $\mathrm{SO}_{\mathrm{x}}$ and $\mathrm{BC}$ emissions rose by roughly $130 \%$ and $56 \%$, respectively, from 1980 2000 (Smith et al., 2001; Bond et al., 2007). Interestingly, Europe's milder climate generally produces less snow cover than equal-latitude regions of Asia, and thus identical aerosol loading over both regions likely produces more negative forcing over Europe. Experiment T1, which includes decreasing European aerosol emissions and no snow darkening, does produce noticeable European warming (Fig. 8c), although this signal is convolved with greenhouse and SST warming.

\section{Conclusions}

We have applied column radiative transfer studies, global climate simulations, temperature and snow cover observations, and CMIP3 model data to explore the influence of carbonaceous particles and snow darkening on springtime climate. Radiative transfer studies show that any mixture of carbonaceous particles induces positive top-of-atmosphere forcing over snow, and darkening caused by minute concentrations of particles within snowpack outweighs dimming forcing from atmospheric constituents, causing net warming at the surface. Boreal spring climate is uniquely sensitive to the presence of absorbing particles because large expanses of bright snow cover are exposed to relatively intense solar radiation.

Emissions of black carbon (BC) and organic matter (OM) drive nearly as much reduction in Eurasian springtime snow cover as anthropogenic $\mathrm{CO}_{2}$ in equilibrium climate experiments initialized with pre-industrial conditions. Cessation of all fossil fuel and biofuel $\mathrm{BC}+\mathrm{OM}$ emissions in present climate causes Eurasia to recover one-quarter of its simulated pre-industrial to present snow cover loss. The warming influence of these emissions is reduced in current climate because of less snow cover and smaller forcing caused by greater presence of biomass burning and mineral dust aerosols.

Snow-albedo feedback is proceeding over springtime Eurasia, which has lost about $14 \%$ of its snow cover since 1979 and warmed more rapidly during the last 30 years $\left(0.64^{\circ} \mathrm{Cdecade}^{-1}\right)$ than most other places and seasons on Earth. These trends are almost universally under-predicted by models contributing to the IPCC Fourth Assessment Report. Snow darkening from deposited $\mathrm{BC}$ and mineral dust particles, not represented by these models, exerts threefold greater springtime energy forcing on Eurasian snow $\left(3.9 \mathrm{~W} \mathrm{~m}^{-2}\right)$ than North American snow. This forcing reduces snow on the southern boundary of snow extent and drives amplified Eurasian warming, significantly improving simulated continental temperature trends. Springtime snow cover trends are only marginally improved with snow darkening, however, reinforcing the complicated interplay between greenhouse warming, aerosol scattering and absorption, snow extent and darkening, land cover change, and climate variability.

Our results highlight unique feedback between aerosol forcing and springtime climate. Through solar heating of the air above and within snowpack, particles induce early ablation of springtime snow, triggering snow-albedo feedback that warms present and pre-industrial climate. But snow cover can also determine the sign of net aerosol forcing. Therefore as snow continues to recede, regionally-averaged net aerosol forcing will likely become more negative, exerting a cooling influence that could constitute a long-term negative feedback on climate. 
Appendix A.

CMIP3 Models.

Table A1. Coupled Model Intercomparison Project (CMIP3) Model Experiments.

\begin{tabular}{|c|c|c|c|c|}
\hline $\begin{array}{l}\text { Model } \\
\text { Number }^{\mathrm{a}}\end{array}$ & $\begin{array}{l}\text { Model } \\
\text { Name }^{\mathrm{b}}\end{array}$ & $\begin{array}{l}\text { Number of } \\
\text { Ensemble } \\
\text { Members }\end{array}$ & $\begin{array}{l}\text { Variables used } \\
\text { for } \mathrm{SCE}^{\mathrm{c}}\end{array}$ & $\begin{array}{l}\text { Trend } \\
\text { Period }\end{array}$ \\
\hline \multicolumn{5}{|c|}{ Coupled atmosphere-ocean simulations of the 20th Century ("AOGCM") } \\
\hline 1 & BCCR-BCM2.0 & 1 & snw & 1979-1999 \\
\hline 2 & CCSM3 & 6 & snc & 1979-1999 \\
\hline 3 & CGCM3.1(T63) & 1 & snc & 1979-2000 \\
\hline 4 & CNRM-CM3 & 1 & snw & 1979-1999 \\
\hline 5 & CSIRO-Mk3.0 & 2 & snc & 1979-2000 \\
\hline 6 & ECHAM5 & 4 & snw & 1979-2000 \\
\hline 7 & ECHO-G & 5 & snd & 1979-2000 \\
\hline 8 & FGOALS-g1.0 & 2 & snc & 1979-1999 \\
\hline 9 & GFDL-CM2.0 & 3 & snw & 1979-2000 \\
\hline 10 & GFDL-CM2.1 & 3 & snw & 1979-2000 \\
\hline 11 & GISS-AOM & 2 & snc & 1979-2000 \\
\hline 12 & GISS-EH & 5 & snc & 1979-1999 \\
\hline 13 & GISS-ER & 8 & snc & 1979-2000 \\
\hline 14 & INGV & 1 & snd & 1979-2000 \\
\hline 15 & INM-CM3.0 & 1 & snc & 1979-2000 \\
\hline 16 & IPSL-CM4 & 2 & snc & 1979-2000 \\
\hline 17 & MIROC3.2(medres) & 3 & snc & 1979-2000 \\
\hline 18 & MIROC3.2(hires) & 1 & snc & 1979-2000 \\
\hline 19 & MRI-CGCM2.3.2 & 5 & snc & 1979-2000 \\
\hline 20 & PCM1 & 4 & snd & 1979-1999 \\
\hline 21 & UKMO-HadCM3 & 2 & snw & 1979-1999 \\
\hline 22 & UKMO-HadGEM1 & 2 & snw & 1979-1999 \\
\hline
\end{tabular}

Simulations forced with observed sea surface temperatures and sea-ice ("SST-forced")

\begin{tabular}{lllll}
\hline 2 & CCSM3 & 1 & snc & $1979-2000$ \\
4 & CNRM-CM3 & 1 & snw & $1979-2000$ \\
6 & ECHAM5 & 3 & snw & $1979-1999$ \\
8 & FGOALS-g1.0 & 2 & snd & $1979-2000$ \\
10 & GFDL-CM2.1 & 1 & snw & $1980-1999$ \\
13 & GISS-ER & 4 & snc & $1979-2000$ \\
15 & INM-CM3.0 & 1 & snc & $1979-2000$ \\
16 & IPSL-CM4 & 5 & snc & $1979-2000$ \\
17 & MIROC3.2(medres) & 3 & snc & $1979-2000$ \\
18 & MIROC3.2(hires) & 1 & snc & $1979-2000$ \\
19 & MRI-CGCM2.3.2 & 1 & snc & $1979-2000$ \\
20 & PCM1 & 1 & snd & $1979-1997$ \\
22 & UKMO-HadGEM1 & 1 & snw & $1979-2000$ \\
\hline
\end{tabular}

a Corresponds with abscissa number in Figs. 5 and 6.

b CMIP3 Model ID. Descriptions of models included in the IPCC AR4 (Randall et al., 2007) and at: http://www-pcmdi.llnl.gov/ipcc/model_documentation/ipcc_model_documentation.php.

c Variables used to derive snow cover extent: "snc"=snow cover fraction, "snd"=snow depth, "snw"=snow mass. 
Acknowledgements. We thank two anonymous reviewers for instructive comments. The National Center for Atmospheric Research (NCAR) is sponsored by the National Science Foundation. We acknowledge the modeling groups, the Program for Climate Model Diagnosis and Intercomparison (PCMDI) and the WCRP's Working Group on Coupled Modelling (WGCM) for their roles in making available the WCRP CMIP3 multi-model dataset. Support of this dataset is provided by the Office of Science, U.S. Department of Energy. Research supported by the NCAR Advanced Study Program and NSF-0758369 (via Cornell University). We thank John Fasullo for processed snow cover data used in Fig. 2. Computations supported by Earth System Modeling Facility NSF ATM-0321380 and NCAR facilities.

Edited by: U. Lohmann

\section{References}

Ammann, C., Meehl, G., Washington, W., and Zender, C.: A Monthly and Latitudinally Varying Volcanic Forcing Dataset in Simulations of 20th Century Climate, Geophys. Res. Lett., 30, 1657, doi:10.1029/2003GL016875, 2003.

Andreae, M. O. and Merlet, P.: Emission of trace gases and aerosols from biomass burning, Global Biogeochem. Cy., 15, 955-966, 2001.

Aoki, T., Aoki, T., Fukabori, M., and Uchiyama, A.: Numerical simulations of the atmospheric effects on snow albedo with a multiple scattering radiative transfer model for the snowatmosphere system, J. Meteorol. Soc. Jpn, 77, 595-614, 1999.

Armstrong, R. L. and Brodzik, M. J.: Northern Hemisphere EASEGrid weekly snow cover and sea ice extent version 3, Boulder, CO, USA: National Snow and Ice Data Center, Digital media, 2005.

Bond, T. C. and Bergstrom, R. W.: Light absorption by carbonaceous particles: An investigative review, Aerosol Sci. Technol., 40, 27-67, doi:10.1080/02786820500421521, 2006.

Bond, T. C., Streets, D. G., Yarber, K. F., Nelson, S. M., Woo, J.H., and Klimont, Z.: A technology-based global inventory of black and organic carbon emissions from combustion, J. Geophys. Res., 109, D14203, doi:10.1029/2003JD003697, 2004.

Bond, T. C., Habib, G., and Bergstrom, R. W.: Limitations in the enhancement of visible light absorption due to mixing state, J. Geophys. Res., 111, D20211, doi:10.1029/2006JD00731, 2006.

Bond, T. C., Bhardwaj, E., Dong, R., Jogani, R., Jung, S., Roden, C., Streets, D. G., and Trautmann, N. M.: Historical emissions of black and organic carbon aerosol from energy-related combustion, 1850-2000, Global Biogeochem. Cy., 21, GB2018, doi: 10.1029/2006GB002840, 2007.

Brohan, P., Kennedy, J. J., Harris, I., Tett, S. F. B., and Jones, P. D.: Uncertainty estimates in regional and global observed temperature changes: A new dataset from 1850, J. Geophys. Res., 111, D12106, doi:10.1029/2005JD006548, 2006.

Brown, R. D. and Frei, A.: Comment on "Evaluation of surface albedo and snow cover in AR4 coupled models", J. Geophys. Res., 112, D22102, doi:10.1029/2006JD008339, 2007.

Cess, R. D.: Arctic aerosols: Model estimates of interactive influences upon the surface-atmosphere clear-sky radiation budget, Atmos. Environ., 17, 2555-2564, 1983.
Chang, H. and Charalampopoulos, T. T.: Determination of the Wavelength Dependence of Refractive Indices of Flame Soot, Proc. Roy. Soc. London A, Math. and Phys. Sci., 430, 577-591, 1990.

Chung, C. E., Ramanathan, V., Kim, D., and Podgorny, I. A.: Global anthropogenic aerosol direct forcing derived from satellite and ground-based observations, J. Geophys. Res., 110, D24207, doi: 10.1029/2005JD006356, 2005.

Coakley, J. A., Cess, R. D., and Yurevich, F. B.: The Effect of tropospheric aerosols on Earth's radiation budget: A parameterization for climate models, J. Atmos. Sci., 40, 116-138, 1983.

Collins, W. D., Rasch, P. J., Eaton, B. E., Khattatov, B., Lamarque, J.-F., and Zender, C. S.: Simulating aerosols using a chemical transport model with assimilation of satellite aerosol retrievals: Methodology for INDOEX, J. Geophys. Res., 106, 7313-7336, 2001.

Collins, W. D., Bitz, C. M., Blackmon, M. L., Bonan, G. B., Bretherton, C. S., Carton, J. A., Chang, P., Doney, S. C., Hack, J. J., Henderson, T. B., Kiehl, J. T., Large, W. G., McKenna, D. S., Santer, B. D., and Smith, R. D.: The Community Climate System Model Version 3 (CCSM3), J. Climate, 19, 2122-2161, 2006.

Conway, H., Gades, A., and Raymond, C. F.: Albedo of Dirty Snow During Conditions of Melt, Water Resour. Res., 32, 1713-1718, 1996.

Déry, S. J. and Brown, R. D.: Recent Northern Hemisphere snow cover extent trends and implications for the snowalbedo-feedback, Geophys. Res. Lett., 34, L22504, doi:10.1029/ 2007GL031474, 2007.

Flanner, M. G. and Zender, C. S.: Snowpack Radiative Heating: Influence on Tibetan Plateau Climate, Geophys. Res. Lett., 32, L06501, doi:10.1029/2004GL022076, 2005.

Flanner, M. G. and Zender, C. S.: Linking snowpack microphysics and albedo evolution, J. Geophys. Res., 111, D12208, doi:10. 1029/2005JD006834, 2006.

Flanner, M. G., Zender, C. S., Randerson, J. T., and Rasch, P. J.: Present day climate forcing and response from black carbon in snow, J. Geophys. Res., 112, D11202, doi:10.1029/ 2006JD008003, 2007.

Frei, A., Miller, J. A., and Robinson, D. A.: Improved simulations of snow extent in the second phase of the Atmospheric Model Intercomparison Project (AMIP-2), J. Geophys. Res., 108(D12), 4369, doi:10.1029/2002JD003030, 2003.

Hall, A. and Qu, X.: Using the current seasonal cycle to constrain snow albedo feedback in future climate change, Geophys. Res. Lett., 33, L03502, doi:10.1029/2005GL025127, 2006.

Hansen, J. and Nazarenko, L.: Soot Climate Forcing via Snow and Ice Albedos, PNAS, 101, 423-428, 2004.

Hansen, J., Ruedy, R., Sato, M., Imhoff, M., Lawrence, W., Easterling, D., Peterson, T., and Karl, T.: A closer look at United States and global surface temperature trends, J. Geophys. Res., 106, 23947-23963, 2001.

Hansen, J., Sato, M., Ruedy, R., Nazarenko, L., Lacis, A., Schmidt, G. A., Russell, G., Aleinov, I., Bauer, M., Bauer, S., Bell, N., Cairns, B., Canuto, V., Chandler, Cheng, Y., Genio, A. D., Faluvegi, G., Fleming, E., Friend, A., Hall, T., Jackman, C., Kelley, M., Kiang, N., Koch, D., Lean, J., Lerner, J., Lo, K., Menon, S., Miller, R., Minnis, P., Novakov, T., Oinas, V., Perlwitz, J., Perlwitz, J., Rind, D., Romanou, A., Shindell, D., Stone, P., Sun, S., 
Tausnev, N., Thresher, D., Wielicki, B., Wong, T., Yao, M., and Zhang, S.: Efficacy of climate forcings, J. Geophys. Res., 110, D18104, doi:10.1029/2005JD005776, 2005.

Hansen, J., Sato, M., Ruedy, R., Kharecha, P., Lacis, A., Miller, R., Nazarenko, L., Lo, K., Schmidt, G., Russell, G., Aleinov, I., Bauer, S., Baum, E., Cairns, B., Canuto, V., Chandler, M., Cheng, Y., Cohen, A., Genio, A. D., Faluvegi, G., Fleming, E., Friend, A., Hall, T., Jackman, C., Jonas, J., Kelley, M., Kiang, N., Koch, D., Labow, G., Lerner, J., Menon, S., Novakov, T., Oinas, V., Perlwitz, J., Perlwitz, J., Rind, D., Romanou, A., Schmunk, R., Shindell, D., Stone, P., Sun, S., Streets, D., Tausnev, N., Thresher, D., Unger, N., Yao, M., and Zhang, S.: Climate simulations for 1880-2003 with GISS modelE, Clim. Dynam., 29, 661-696, doi:10.1007/s00382-007-0255-8, 2007.

Hess, M., Koepke, P., and Schult, I.: Optical Properties of Aerosols and Clouds: The Software Package OPAC, Bull. Am. Meteorol. Soc., 79, 831-844, 1998.

Hurrell, J. W., Kushnir, Y., and Visbeck, M.: Climate: The North Atlantic Oscillation, Science, 291, 603-605, 2001.

Jacobson, M.: Strong Radiative Heating Due to the Mixing State of Black Carbon, Nature, 409, 695-697, 2001.

Jacobson, M. Z.: Climate response of fossil fuel and biofuel soot, accounting for soot's feedback to snow and sea ice albedo and emissivity, J. Geophys. Res., 109, D21201, doi:10.1029/ 2004JD004945, 2004.

Koch, D. and Hansen, J.: Distant origins of Arctic black carbon: A Goddard Institute for Space Studies ModelE experiment, J. Geophys. Res., 110, D04204, doi:10.1029/2004JD005296, 2005.

Lamarque, J.-F., Hess, P. G., Emmons, L., Buja, L., Washington, W., and Granier, C.: Tropospheric ozone evolution between 1890 and 1990, J. Geophys. Res., 110, D08304, doi: 10.1029/2004JD005537, 2005.

Lemke, P., Ren, P. J., Alley, R. B., Allison, I., Carrasco, J., Flato, G., Fujii, Y., Kaser, G., Mote, P., Thomas, R. H., and Zhang, T.: Observations: Changes in Snow, Ice, and Frozen Ground, in: Climate Change 2007: The Physical Science Basis, Cambridge University Press, UK, 2007.

Levis, S., Bonan, G. B., and Lawrence, P. J.: Present-day springtime high-latitude surface albedo as a predictor of simulated climate sensitivity, Geophys. Res. Lett., 34, L17703, doi:10.1029/ 2007GL030775, 2007.

Mahowald, N. M., Muhs, D. R., Levis, S., Rasch, P. J., Yoshioka, M., Zender, C. S., and Luo, C.: Change in atmospheric mineral aerosols in response to climate: Last glacial period, preindustrial, modern, and doubled carbon dioxide climates, J. Geophys. Res., 111, D10202, doi:10.1029/2005JD006653, 2006.

McConnell, J. R., Edwards, R., Kok, G. L., Flanner, M. G., Zender, C. S., Saltzman, E. S., Banta, J. R., Pasteris, D. R., Carter, M. M., and Kahl, J. D. W.: 20th-Century industrial black carbon emissions altered Arctic climate forcing, Science, 317, 1381-1384, 2007.

Ming, J., Cachier, H., Xiao, C., Qin, D., Kang, S., Hou, S., and $\mathrm{Xu}, \mathrm{J}$.: Black carbon record based on a shallow Himalayan ice core and its climatic implications, Atmos. Chem. Phys., 8, 13431352, 2008, http://www.atmos-chem-phys.net/8/1343/2008/.

Munneke, P. K., Reijmer, C. H., van den Broeke, M. R., KönigLanglo, G., Stammes, P., and Knap, W. H.: Analysis of clear-sky Antarctic snow albedo using observations and radiative trans- fer modeling, J. Geophys. Res., 113, D17118, doi:10.1029/ 2007JD009653, 2008.

Myhre, G., Highwood, E. J., Shine, K. P., and Stordal, F.: New estimates of radiative forcing due to well mixed greenhouse gases, Geophys. Res. Lett., 25, 2715-2718, 1998.

Niu, G.-Y. and Yang, Z.-L.: An observation-based formulation of snow cover fraction and its evaluation over large North American river basins, J. Geophys. Res., 112, D21101, doi:10.1029/ 2007JD008674, 2007.

Nolin, A. W. and Dozier, J.: Estimating snow grain size using AVIRIS data, Remote. Sens. Environ., 44, 231-238, 1993.

Ogren, J. A. and Charlson, R. J.: Elemental carbon in the atmosphere: Cycle and lifetime, Tellus, 35B, 241-254, 1983.

Painter, T. H., Barrett, A. P., Landry, C. C., Neff, J. C., Cassidy, M. P., Lawrence, C. R., McBride, K. E., and Farmer, G. L.: Impact of disturbed desert soils on duration of mountain snow cover, Geophys. Res. Lett., 34, L12502, doi:10.1029/ 2007GL030284, 2007.

Pfister, G. G., Hess, P. G., Emmons, L. K., Rasch, P. J., and Vitt, F. M.: Impact of the summer 2004 Alaska fires on top of the atmosphere clear-sky radiation fluxes, J. Geophys. Res., 113, D02204, doi:10.1029/2007JD008797, 2008.

Pierce, D. W., Barnett, T. P., Hidalgo, H. G., Das, T., Bonfils, C., Santer, B. D., Bala, G., Dettinger, M. D., Cayan, D. R., Mirin, A., Wood, A. W., , and Nozawa, T.: Attribution of declining Western U.S. snowpack to human effects, J. Climate, 21, 6425-6444, doi: 10.1175/2008JCLI2405.1, 2008.

Qian, T., Dai, A., Trenberth, K. E., and Oleson, K. W.: Simulation of Global Land Surface Conditions from 1948 to 2004. Part I: Forcing Data and Evaluations, J. Hydrometeorol., 7, 953-975, 2006.

Qu, X. and Hall, A.: Surface Contribution to Planetary Albedo Variability in Cryosphere Regions, J. Climate, 18, 5239-5252, 2005.

Ramanathan, V. and Carmichael, G.: Global and regional climate changes due to black carbon, Nature Geosci., 1, 221-227, 2008.

Ramanathan, V., Crutzen, P. J., , Lelieveld, J., Mitra, A. P., Althausen, D., Anderson, J., Andreae, M. O., Cantrell, W., Cass, G. R., Chung, C. E., Clarke, A. D., Coakley, J. A., Collins, W. D., Conant, W. C., Dulac, F., Heintzenberg, J., Heymsfield, A. J., Holben, B., Howell, S., Hudson, J., Jayaraman, A., Kiehl, J. T., Krishnamurti, T. N., Lubin, D., McFarquhar, G., Novakov, T., Ogren, J. A., Podgorny, I. A., Prather, K., Priestley, K., Prospero, J. M., Quinn, P. K., Rajeev, K., Rasch, P., Rupert, S., Sadourny, R., Satheesh, S. K., Shaw, G. E., Sheridan, P., and Valero, F. P. J.: Indian Ocean Experiment: An integrated analysis of the climate forcing and effects of the great Indo-Asian haze, J. Geophys. Res., 106, 28371-28398, 2001.

Ramanathan, V., Ramana, M. V., Roberts, G., Kim, D., Corrigan, C., Chung, C., and Winker, D.: Warming trends in Asia amplified by brown cloud solar absorption, Nature, 448, 575-578, doi:10. 1038/nature06019, 2007.

Randall, D. A., Wood, R. A., Bony, S., Colman, R., Fichefet, T., Fyfe, J., Kattsov, V., Pitman, A., Shukla, J., Srinivasan, J., Stouffer, R. J., Sumi, A., and Taylor, K. E.: Climate models and their evaluation, in: Climate Change 2007: The Physical Science Basis, Cambridge University Press, UK, 2007.

Rasch, P. J., Barth, M. C., Kiehl, J. T., Schwartz, S. E., and Benkovitz, C. M.: A description of the global sulfur cycle and its controlling processes in the National Center for Atmospheric Re- 
search Community Climate Model, J. Geophys. Res., 105, 13671385, 2000.

Rasch, P. J., Collins, W. D., and Eaton, B. E.: Understanding the Indian Ocean Experiment (INDOEX) aerosol distributions with an aerosol assimilation, J. Geophys. Res., 106, 7337-7355, 2001.

Rayner, N. A., Parker, D. E., Horton, E. B., Folland, C. K., Alexander, L. V., Rowell, D. P., Kent, E. C., and Kaplan, A.: Global analysis of sea surface temperature, sea ice, and night marine air temperature since the late 19th century, J. Geophys. Res., 108(D14), 4407, doi:10.1029/2002JD002670, 2003.

Robinson, D. A. and Frei, A.: Seasonal variability of northern hemisphere snow extent using visible satellite data, Prof. Geogr., 51, 307-314, 2000.

Rodwell, M. J., Rowell, D. P., and Folland, C. K.: Oceanic forcing of the wintertime North Atlantic Oscillation and European climate, Nature, 398, 320-323, 1999.

Roesch, A.: Evaluation of surface albedo and snow cover in AR4 coupled climate models, J. Geophys. Res., 111, D15111, doi: 10.1029/2005JD006473, 2006.

Ruckstuhl, C., Philipona, R., Behrens, K., Coen, M. C., Durr, B., Heimo, A., Matzler, C., Nyeki, S., Ohmura, A., Vuilleumier, L., Weller, M., Wehrli, C., and Zelenka, A.: Aerosol and cloud effects on solar brightening and the recent rapid warming, Geophys. Res. Lett., 35, L12708, doi:10.1029/2008GL034228, 2008.

Russell, L. M.: Aerosol organic-mass-to-organic-carbon ratios, Environ. Sci. Technol., 37, 2982-2987, 2003.

Sahu, S. K., Beig, G., and Sharma, C.: Decadal growth of black carbon emissions in India, Geophys. Res. Res., 35, L02807, doi: 10.1029/2007GL032333, 2008.

Shindell, D. T., Chin, M., Dentener, F., Doherty, R. M., Faluvegi, G., Fiore, A. M., Hess, P., Koch, D. M., MacKenzie, I. A., Sanderson, M. G., Schultz, M. G., Schulz, M., Stevenson, D. S., Teich, H., Textor, C., Wild, O., Bergmann, D. J., Bey, I., Bian, H., Cuvelier, C., Duncan, B. N., Folberth, G., Horowitz, L. W., Jonson, J., Kaminski, J. W., Marmer, E., Park, R., Pringle, K. J., Schroeder, S., Szopa, S., Takemura, T., Zeng, G., Keating, T. J., and Zuber, A.: A multi-model assessment of pollution transport to the Arctic, Atmos. Chem. Phys., 8, 5353-5372, 2008, http://www.atmos-chem-phys.net/8/5353/2008/.

Smith, S. J.,Pitcher, H. Â., and Wigley, T.: Global and regional anthropogenic sulfur dioxide emissions, Global Planet. Change, 29, 99-119, 2001.

Stamnes, K., Tsay, S.-C., Wiscombe, W., and Jayaweera, K.: Numerically Stable Algorithm for Discrete-ordinate-method radiative transfer in multiple scattering and emitting layered media, Appl. Optics, 27, 2502-2509, 1988.

Stewart, I. T., Cayan, D. R., and Dettinger, M. D.: Changes toward earlier streamflow timing across Western North America, J. Climate, 18, 1136-1155, 2005.
Stohl, A.: Characteristics of atmospheric transport into the Arctic troposphere, J. Geophys. Res., 111, D11306, doi:10.1029/ 2005JD006888, 2006.

Stone, R. S., Anderson, G. P., Shettle, E. P., Andrews, E., Loukachine, K., Dutton, E. G., Schaaf, C., and Roman III, M. O.: Radiative impact of boreal smoke in the Arctic: Observed and modeled, J. Geophys. Res., 113, D14S16, doi:10.1029/ 2007JD009657, 2008.

Toon, O. B., McKay, C. P., Ackerman, T. P., and Santhanam, K.: Rapid calculation of radiative heating rates and photodissociation rates in inhomogeneous multiple scattering atmospheres, J. Geophys. Res., 94, 16287-16301, 1989.

Trenberth, K. E., Jones, P. D., Ambenje, P., Bojariu, R., Easterling, D., Tank, A. K., Parker, D., Rahimzadeh, F., Renwick, J. A., Rusticucci, M., Soden, B., and Zhai, P.: Observations: Surface and Atmospheric Climate Change, in: Climate Change 2007: The Physical Science Basis, Cambridge University Press, UK, 2007.

van der Werf, G. R., Randerson, J. T., Giglio, L., Collatz, G. J., Kasibhatla, P. S., and Arellano Jr., A. F.: Interannual variability in global biomass burning emissions from 1997 to 2004, Atmos. Chem. Phys., 6, 3423-3441, 2006, http://www.atmos-chem-phys.net/6/3423/2006/.

Wang, L., Sharp, M., Brown, R., Derksen, C., and Rivard, B.: Evaluation of spring snow covered area depletion in the Canadian Arctic from NOAA snow charts, Remote Sens. Environ., 95, 453-463, 2005

Warren, S.: Optical Properties of Snow, Rev. Geophys., 20, 67-89, 1982

Warren, S. and Wiscombe, W.: A Model for the Spectral Albedo of Snow. II: Snow Containing Atmospheric Aerosols, J. Atmos. Sci., 37, 2734-2745, 1980.

Wiscombe, W. J. and Warren, S. G.: A Model for the Spectral Albedo of Snow. I: Pure Snow, J. Atmos. Sci., 37, 2712-2733, 1980

Yue, S., Pilon, P., Phinney, B., and Cavadias, G.: The influence of autocorrelation on the ability to detect trend in hydrologic series, Hydrol. Process., 16, 1807-1829, doi:10.1002/hyp.1095, 2002.

Zender, C., Bian, H., and Newman, D.: Mineral Dust Entrainment and Deposition (DEAD) Model: Description and 1990s Dust Climatology, J. Geophys. Res., 108(D14), 4416, doi:10.1029/ 2002JD002775, 2003.

Zender, C. S., Bush, B., Pope, S. K., Bucholtz, A., Collins, W. D., Kiehl, J. T., Valero, F. P. J., and Vitko Jr., J.: Atmospheric absorption during the Atmospheric Radiation Measurement (ARM) Enhanced Shortwave Experiment (ARESE), J. Geophys. Res., 102, 29901-29915, 1997. 